\title{
LA CONVOCATORIA A LA INTERVENCIÓN MILITAR EN CHILE EN LA GUERRA CIVIL DE 1891*
}

\author{
Alejandro San Francisco
}

El presente artículo se refiere a los llamados reiterados hechos por el gobierno de Balmaceda (1886-1891) y la oposición parlamentaria para que los militares intervinieran en política y los favorecieran a cada uno de ellos en la lucha de poder que se libraba en Chile desde mediados de esa administración. Especial importancia tiene la prensa de diciembre de 1890, que apela pública y explícitamente a los uniformados, en el sentido de defender al Presidente de la República en virtud del principio de obediencia y no deliberación de las Fuerzas Armadas (prensa balmacedista) o bien promoviendo la sublevación contra él de acuerdo con el derecho de rebelión contra un gobierno dictatorial que se salía de los márgenes de la Constitución y de las leyes (como estimaban los opositores). Como resultado, la resolución del conflicto fue de carácter armado, como lo mostró la guerra civil que se desarrolló entre enero y agosto de 1891. De esta manera, la convocatoria a la intervención militar en la guerra civil de 1891 se transforma en un antecedente - que requiere un estudio comparativo- de las intervenciones y golpes militares del siglo $\mathrm{XX}$.

Alejandro San Francisco. Profesor del Instituto de Historia y la Facultad de Derecho de la Universidad Católica de Chile. Editor de Bicentenario. Revista de Historia de Chile y América.

* El autor agradece especialmente a Alan Angell, por sus sugerencias y comentarios a una primera versión de este artículo, y a Claudia Castillo por su contribución en la realización de esta investigación. 


\section{Introducción}

E.

2003, con ocasión de cumplirse los treinta años del 11 de septiembre de 1973, se desarrolló un debate que involucró a las Fuerzas Armadas y a los académicos, en relación a la intervención militar que puso fin al gobierno socialista de la Unidad Popular ${ }^{1}$. Como resultado de la discusión, también se volvieron los ojos hacia los golpes militares de 192425 , que habrían marcado el inicio de la presencia de los uniformados en política chilena, como suele señalar la historiografía ${ }^{2}$. Según ha sido tradicional en Chile, la guerra civil de 1891 es excluida del análisis de las intervenciones militares, en circunstancias que es, a nuestro juicio, un antecedente clave para entender mejor los golpes militares del siglo XX. Al conflicto de 1891 se lo caracteriza generalmente de una manera diferente, en el cual se habrían enfrentado un Ejército más favorable a la obediencia debida al Presidente de la República, contra una Marina cercana a los sectores aristocráticos del puerto de Valparaíso y partidaria de los ideales del parlamentarismo inglés ${ }^{3}$. El asunto, sin embargo, es mucho más complejo, y la guerra civil de 1891 tiene movimientos desde el Ejército tanto en la dirección opositora como en la gubernamental, como se comprobaría en el preludio de la guerra civil y durante los ocho meses que duró el conflicto. La deliberación política de los militares, que precedió al estallido de la guerra y que fue pública y permanente, tiene mucho que ver en esto ${ }^{4}$. También es importante el hecho de que tanto el gobierno de Balmaceda como sus detractores hayan decidido convocar expresamente a las Fuerzas Armadas a intervenir, ante la inminencia de producirse la crisis constitucional a fines de 1890 y comienzos de 1891 . De esto último se trata, precisamente, el presente artículo.

Diciembre de 1890 no fue un mes normal en la historia de Chile, como se comprobaría pronto al comenzar el año siguiente. Un periódico

${ }^{1}$ Por ejemplo, Cheyre, Juan Emilio: “2003: Un Desafío Futuro”, La Tercera, 5 de enero de 2003; San Francisco, Alejandro: "El Ejército, la Historia y la Responsabilidad Institucional", La Segunda, 6 de enero de 2003; y la polémica entre Arturo Fontaine T. y Gonzalo Rojas S. recogida en "Debate sobre la Posición de las FF.AA. frente al Gobierno Militar", 2003, pp. 301-310.

${ }^{2} \mathrm{Al}$ respecto, Nunn, Frederick: Chilean Politics, 1920-1931: The Honorable Mission of the Armed Forces, 1970, pp. 2, 5 y 47-48; Vial, Gonzalo: Historia de Chile. Vol. 3, Alessandri y los Golpes Militares, 2001, p. 408; Millar, René: "Significado y Antecedentes del Movimiento Militar de 1924”, 1972-1973, pp. 7-102.

${ }^{3}$ Edwards, Alberto: La Fronda Aristocrática, 1992 (13 edición), Caps. XXIX y XX; Góngora, Mario: Ensayo Histórico sobre la Noción de Estado en Chile en los Siglos XIX y XX, 2003 ( $8^{a}$ edición), pp. 102-103.

${ }^{4}$ San Francisco, Alejandro: "La Deliberación Política de los Militares Chilenos en el Preludio de la Guerra Civil de 1891”, por publicarse. 
extranjero que circulaba en el puerto de Valparaíso, The Chilian Times, declaraba a fines de ese mes: "Esperamos que las disensiones que por largo tiempo han dividido y perturbado al país se acaben con el término de 1890, y que una nueva era más brillante sea inaugurada con el Año Nuevo"5. El problema de fondo, todos lo sabían, era que el conflicto que durante el año había enfrentado al Presidente Balmaceda contra la oposición parlamentaria no podía seguir estirándose sin hacer peligrar las instituciones republicanas y la continuidad constitucional. De hecho, la carta de 1833 fijaba una fecha límite para las disensiones —el $1^{\circ}$ de enero de 1891-, momento después del cual o se arribaba a una solución aceptable por las partes o el agrio debate político podía derivar en una intervención armada, en forma de guerra civil, golpe de Estado o revolución. En cualquiera de los casos, sería una demostración más de la incapacidad de los sectores dirigentes por encontrar fórmulas de convivencia estables en el tiempo y mostraría que Chile no estaba ajeno ni inmune a las revoluciones y problemas que habían caracterizado al siglo XIX hispanoamericano ${ }^{6}$. Ya durante la crisis provocada por la censura al Ministerio de Mayo, liderado por Enrique S. Sanfuentes, el país había estado al borde del precipicio y se llegó a hablar de la clausura del Congreso, la renuncia del Presidente de la República y una eventual resolución militar al conflicto político ${ }^{7}$.

La Constitución de 1833 establecía que correspondía al Congreso Nacional dictar anualmente dos leyes, denominadas "leyes periódicas" o constitucionales: la de presupuesto anual de la Nación y aquella que fijaba las fuerzas de mar y tierra ${ }^{8}$. El Congreso, sin embargo, se encontraba clausurado desde octubre, cuando Balmaceda decidió poner fin a su período de sesiones extraordinarias, nombrando un nuevo gabinete encabezado por Claudio Vicuña. El Presidente, por otra parte, no manifestaba el menor

${ }^{5}$ The Chilian Times, 27 de diciembre de 1890.

${ }^{6}$ A pesar de la gravedad de la situación, Balmaceda mostraba un orgullo patriótico por el desarrollo histórico y la situación de Chile en ese entonces, como señaló a mediados de 1890: "Chile ha sido en el período de su organización una excepción entre las Repúblicas fundadas en el siglo XIX; y en los últimos treinta años ofrece un ejemplo sin igual en los continentes de ambas Américas, y acaso sin paralelo en el resto del mundo. Mientras las naciones han sufrido graves agitaciones sociales y políticas, cambios imprevistos de Gobiernos y profundas revoluciones, la República de Chile no ha sufrido, a pesar de la situación extraordinaria creada por una formidable guerra exterior, ni un solo trastorno político, ni un solo motín militar. Ni por un instante se ha perturbado la marcha de sólido progreso realizado por una y otra generación", en Balmaceda, José Manuel: "Mensaje Presidencial de 1890", pp. 5-9.

${ }^{7}$ Para revisar los sucesos políticos de Chile en 1890 son especialmente útiles, entre varios autores que se han referido al tema, Bañados Espinosa, Julio: Balmaceda, su Gobierno y la Revolución de 1891, 1894, Tomo I, pp. 409-701; Encina, Francisco Antonio: Historia de Chile, 1970 (2 edición), Tomo XIX, pp. 187-326.

${ }^{8}$ Constitución Política de la República, 1833, Art. 28 (37 en el texto original). 
interés por convocar a sesionar al Congreso (quizá porque se encontraría con la desagradable sorpresa de una censura o una acusación constitucional contra sus ministros); la oposición gastaba todas sus municiones a través de la prensa y la Comisión Conservadora, donde se proferían repetidos ataques a la persona de Balmaceda y de sus ministros y partidarios ${ }^{9}$. Ni el gobierno ni la oposición demostraban un interés real por solucionar el conflicto político y las páginas de los periódicos escalaban una espiral peligrosa de descalificaciones, amenazas y, en definitiva, de un odio político creciente ${ }^{10}$.

Ante esa realidad, quizá sólo cabían dos "soluciones": la claudicación definitiva de uno de los bandos en disputa o bien la imposición por la fuerza de la postura defendida por cada uno de ellos. Esto significaba, en dos palabras, que Balmaceda podía renunciar — como ya se lo habían solicitado dirigentes opositores, apelando a su patriotismo y al ejemplo de O'Higgins-, o bien debía despedir a su gabinete para ser reemplazado por un ministerio parlamentario, acordado con la oposición, como había ocurrido con el Ministerio Prats, de agosto de 1890. También la situación podía modificarse mediante la renuncia de sus posiciones por parte del Congreso, el cual enfrentado a la dura realidad podría haberse mantenido sin mayor intervención en la política del país, aceptando los gabinetes presidenciales de Balmaceda y dejando de lado sus intenciones de querer influir en la marcha de la administración a través de la formación de los ministerios. Sin embargo, ninguno de los contendores se manifestaba dispuesto a ceder, y el paso de los días, en vez de servir para un acuerdo Gobierno-oposición, aumentaba los niveles de violencia verbal y agresiones recíprocas de los balmacedistas y sus contradictores.

La oposición, por ejemplo, fue clara y explícita a partir de octubre: una reunión de los líderes contrarios al gobierno determinó "unir sus esfuerzos para preparar la resistencia por todos los medios legales, mientras el gobierno se mantenga dentro de la Constitución, y por todos los medios posibles cuando salga de ella"11. Desde La Nación, periódico gobiernista, se podían leer las siguientes declaraciones a fines de año: "La ola de malas pasiones amenaza con invadirlo todo y destruir hasta los cimientos del orden público en que hemos vivido desde treinta años: el comercio se

${ }^{9}$ Un documento indispensable para comprender la política chilena a fines de 1890 es Congreso Nacional: Comisión Conservadora, sesión de 16 de octubre a sesión de 24 de diciembre de 1890, 273 páginas.

${ }^{10}$ San Francisco, Alejandro: "Las Batallas de la Pluma: La Prensa y el Odio Político en Chile en el Preludio de la Guerra Civil de 1891", 2004.

${ }^{11}$ Para las resoluciones de esta reunión se puede consultar El Ferrocarril, 21 de octubre de 1890 . 
sentía languidecer por las incertidumbres que crea una situación incierta; la sociedad entera encontraba dudas y vacilaciones" $" 12$.

Frente a lo anterior cabía la alternativa extrema de poner al país fuera de la ley y la Constitución y, por lo tanto, de resolver la situación con un golpe de fuerza encabezado por Balmaceda o por sus detractores. La situación no era cómoda y, ciertamente, resultaba excéntrica desde el punto de vista histórico y planteaba una serie de interrogantes difíciles de contestar. ¿Cómo puede funcionar de manera institucional, en forma, un país que no tiene leyes "constitucionales" aprobadas en la forma prescrita por la Constitución? ¿De qué manera operaría el presupuesto y las fuerzas de mar y tierra en 1891? ¿Qué autoridad tendría Balmaceda si se ponía fuera de la ley? ¿Se convertiría en un dictador o un tirano, como lo llamaban los opositores? ¿Cuál debía ser la actitud de las Fuerzas Armadas ante este caso inédito: debían permanecer bajo el Presidente de la República y ajeno a las luchas de partido o más bien podían desobedecer a un gobernante que había dejado de ser constitucional?

El tema es de la mayor importancia y fue precisamente en relación a este último aspecto donde se concentraron tanto la propaganda gobiernista como la opositora a fines de 1890: el conflicto originalmente político se movía lenta pero inexorablemente en una dirección militar; el dilema Presidente-Congreso se transformaba en un asunto que también involucraba a los uniformados; la vieja prescindencia política de las Fuerzas Armadas chilenas daba paso a la posibilidad de intervención en medio de la crisis institucional, rompiendo de esa manera una larga y orgullosa tradición. Diciembre de 1890 demostraba ser un mes decisivo y las batallas de la oratoria y de la pluma llegaron a uno de sus momentos culminantes, anticipando lo que serían los combates armados del año siguiente.

El caso chileno es particularmente interesante, algo complejo y en ocasiones insuficientemente comprendido, tanto para el conjunto del siglo XIX como para el caso específico de 1891. Por una parte, los militares ejercieron el poder político en diversas ocasiones desde los inicios de la república - los casos de O'Higgins, Freire, Prieto y Bulnes así lo demuestran-, pero en el marco de un régimen predominantemente civil, al menos desde 1831 en adelante, y en especial desde la vigencia de la Constitución de $1833^{13}$. Esto permitió que, pasadas las décadas, Chile fuera considerado un país con vigencia plena del régimen constitucional y ausencia de milita-

${ }^{12}$ La Nación, 26 de diciembre 1890.

${ }^{13}$ Véase por ejemplo, Collier, Simon: "Cuatro Hombres de Armas en la Formación y la Consolidación de la República”, 2003, pp. 16-38. 
rismo, una verdadera excepción en el concierto americano en el siglo de los caudillos, las guerras civiles y desorganización ${ }^{14}$.

Por ello mismo, los gobiernos militares en Chile y la politización de las Fuerzas Armadas, desde el punto de vista historiográfico, quedan reservados al siglo XX, específicamente tras los golpes de 1924-25 y la intervención de 1973. El asunto, sin embargo, es mucho más complejo y distintos antecedentes nos permiten afirmar la presencia de signos claros de abandono de posiciones civilistas con anterioridad al estallido de la guerra civil de fines del siglo XIX, a medida que las Fuerzas Armadas se politizaban y la política se militarizaba. Con ello, quedaban abiertas las puertas para que las instituciones de la defensa nacional tomaran parte por el presidente Balmaceda o por el Congreso, en medio del conflicto abierto por el poder que ellos enfrentaron entre 1889 y 1891. Incluso es posible hacer comparaciones interesantes entre los tres procesos, buscar patrones de comportamiento político y analizar elementos comunes y diferencias entre la última guerra civil del primer siglo de vida republicana y los golpes de Estado del siglo $\mathrm{XX}^{15}$.

En el presente trabajo se pretende abordar dicha problemática y la forma cómo se manifestó a fines de 1890 y comienzos de 1891, es decir, cuando las instituciones militares estuvieron frente al momento de la definición fundamental: permanecer junto al Presidente de la República o rebelarse contra dicha autoridad, como promovían los líderes de la oposición parlamentaria. En un primer momento el texto analiza la politización del Ejército en 1890, como se deduce de diferentes manifestaciones públicas a lo largo del año que generaron una división interna en el Ejército, paralelas a la discusión Presidente-Congreso. En segundo término, el estudio se refiere a un asunto de la mayor importancia y que inaugura la fase final de la crisis: el homenaje que la oposición de Santiago rindió al general Manuel Baquedano, que tuvo consecuencias políticas que se analizaron en la prensa durante varios días. En seguida, el trabajo se detiene en el problema constitucional de la ley que fija las fuerzas de mar y tierra, no aprobada todavía por el Congreso para 1891 y que constituía uno de los fundamentos de la compleja situación jurídica que enfrentaba el país y lo ponía en una situación límite desconocida en el país. A continuación, el artículo aborda

${ }^{14}$ Véase Lieuwen, Edwin: Arms and Politics in Latin America, 1961 (edición revisada) pp. 24 y 29; Johnson, John: The Military and Society in Latin America, 1964, p. 50; Lynch, John: Caudillos in Spanish America 1800-1850, 1992. Respecto de la excepcionalidad de Chile, véanse pp. 83, 130, 235 y 433.

${ }^{15}$ Hemos tratado este tema en San Francisco, Alejandro: "Las Intervenciones Militares en Chile: Patrones y Modelos en la Guerra Civil de 1891, los golpes militares de 1924-25 y la intervención militar de 1973”, 2003. 
la perspectiva del gobierno del Presidente Balmaceda a fines de 1890, cuando insiste en la obediencia sin deliberación, de manera de contar con el respaldo inequívoco y sumiso de los militares. Luego el trabajo se refiere a la postura alternativa presentada por la oposición, que destacaba la posibilidad de una acción de los uniformados contra el gobierno de Balmaceda, a medida que éste optaba por superar los límites de la legalidad y la Constitución. Posteriormente, el texto analiza el comienzo de enero de 1891, cuando el problema constitucional se hizo evidente, el Presidente y el Congreso decidieron un camino sin retorno en sus respectivas posiciones y las Fuerzas Armadas debieron optar por uno u otro bando. Finalmente, el trabajo busca proporcionar una explicación más comprensiva de la actitud del Ejército y la Marina y de sus líderes en 1891, ya que ellos fueron parte esencial en el estallido de la guerra civil y en el desarrollo del conflicto, cerrando un proceso de participación de los militares en la resolución de la insoluble crisis política entre el gobierno y la oposición parlamentaria.

Es necesario presentar una aclaración previa respecto del presente artículo, en relación a que se trata de una "historia del tiempo corto", de la coyuntura, de los acontecimientos, de un espacio brevísimo que no supera los 40 días $^{16}$. Evidentemente, el edificio constitucional había experimentado transformaciones importantes entre 1860 y 1890, particularmente en lo que se refiere a la pérdida de prerrogativas presidenciales y el aumento de los poderes parlamentarios, tanto a nivel del texto de la Constitución como en las prácticas políticas que contribuyeron a formar el sistema parlamentario consuetudinario en $\mathrm{Chile}^{17}$. También es claro que la lucha por el poder que caracterizó la década de 1880, y especialmente en el gobierno de José Manuel Balmaceda, no fue un asunto de un día para otro, sino que representaba la manifestación pública que adquiría la pugna por la influencia política, la capacidad económica del país, la prensa, en definitiva, el poder del Estado ${ }^{18}$. La politización del Ejército tuvo, por su parte, una manifestación abierta durante todo el año que precedió a la guerra civil, no fue un asunto que se precipitara de un día para otro.

Sin embargo, a pesar de todas esas consideraciones, tiene sentido estudiar el "tiempo corto", el período que va desde el 29 de noviembre de

${ }^{16} \mathrm{El}$ concepto es de Fernand Braudel, en El Mediterráneo y el Mundo Mediterráneo en la Época de Felipe II, 2002, Prólogo a la Primera Edición Francesa, Vol. 1, pp. 18-19.

${ }^{17}$ Heise, Julio: Historia de Chile. El Período Parlamentario, 1861-1925, 1974, Tomo I, especialmente pp. 36-67; Silva, Fernando y otros, Historia de Chile, Tomo 4, 1988 (8 edición), pp. 681-704.

${ }^{18}$ Esta visión de la lucha por el poder está, recientemente, en el excelente estudio de Sagredo, Rafael: Vapor al Norte, Tren al Sur: El Viaje Presidencial como Práctica Política en Chile, Siglo XIX, 2001. 
1890 al 7 de enero de 1891, es decir, desde la manifestación en favor del general Baquedano hasta el levantamiento de la Escuadra contra el Presidente Balmaceda. La razón es muy simple: en ese tiempo el conflicto político se agudizó y desaparecieron las fórmulas de solución institucionales; en ese período la política se militarizó y ambos contendores prefirieron mirar a los cuarteles para obtener apoyos y, eventualmente, derrotar al adversario por vías de hecho; por último, es posible y necesario estudiar el tiempo corto porque el $1^{\circ}$ de enero se acababa el plazo fatal, ese día el país amanecería sin leyes de presupuesto y leyes de las Fuerzas Armadas, poniendo sobre Chile y los hombres de esos días el sabor de lo desconocido e indeseado: la guerra civil, que dejaría miles de muertos en los campos de batalla y que pondría la vergüenza donde antes se encontraba el orgullo nacional por el desarrollo republicano alcanzado.

\section{La politización del Ejército en 1890}

Sin duda el gran hito militar en tiempos de José Manuel Balmaceda se refirió al proceso de modernización del Ejército, sobre la base del sistema alemán, que llevó a Chile el coronel teutón Emilio Körner. El objetivo de la misión alemana era profesionalizar ("prusianizar") a los militares chilenos, que si bien habían resultado victoriosos en la Guerra del Pacífico (1879-1884) y contaban con orgullo sus hazañas, carecían del conocimiento científico de la "ciencia militar". Así lo ha entendido la historiografía, que ha dedicado numerosos estudios al tema, varios de ellos de gran calidad y con trabajo en las fuentes primarias ${ }^{19}$. A dicha modernización del Ejército se sumó la fuerte inversión económica que hizo el gobierno de Balmaceda en buques para la Armada y armas para el Ejército, símbolo de la importancia que se atribuía entonces al poder armado y también una expresión evidente de las posibilidades ciertas de que el país tuviera que enfrentar un nuevo conflicto bélico internacional con alguno de sus países $\operatorname{vecinos}^{20}$.

${ }^{19}$ La bibliografía al respecto es abundante. Algunos de los trabajos más importantes son Nunn, Frederick: "Emil Körner and the Prussianization of the Chilean Army: Origins, Process and Consequences, 1885-1920", 1970, pp. 300-22; Quiroga, Patricio y Carlos Maldonado: El Prusianismo en las Fuerzas Armadas chilenas: Un Estudio Histórico, 1885-1945, 1988; Blancpain, Jean-Pierre: "L’Armée Chilienne et les Instructeurs Allemands en Amérique Latine (1885-1914)", 1991, pp. 347-393; Brahm, Enrique: Preparados para la Guerra: Pensamiento Militar Chileno bajo Influencia Alemana 1885-1930, 2003; Sater, William y Holger Herwig: The Grand Illusion. The Prussianization of the Chilean Army, 1999.

${ }^{20}$ Ibarrola, Bernardo: "El Ejército de Balmaceda: Modernización y Crisis. Las fuerzas chilenas de mar y tierra, 1884-1890", 2003; Núñez P., Jorge: "La Política Militar del Presidente Balmaceda", 1993, pp. 65-71. 
El asunto fundamental en el plano militar, sin embargo, debe ser complementado con otro aspecto. Junto a la profesionalización anhelada se desarrolló paralelamente su contrapartida, una politización del Ejército; adicionalmente, la guerra internacional no llegó, pero sí lo hizo una guerra civil de consecuencias desastrosas para el país, una de cuyas manifestaciones más interesantes se refiere precisamente a la presencia de los uniformados en los diferentes bandos que disputaban el poder. La actuación de los militares chilenos en la política contingente de fines del siglo XIX ha sido un tema olvidado por la historiografía y no hay análisis completos, de conjunto, basados en investigaciones originales, que den cuenta de un asunto que estimamos de la mayor importancia, si bien numerosas fuentes documentales e impresas ponen de manifiesto —en ocasiones de manera detallada - la progresiva presencia de los uniformados en las actividades y luchas de partidos, así como también los llamados evidentes, abiertos, en ocasiones sistemáticos, hechos por los medios de gobierno y de oposición hacia los soldados en orden a influirlos para que ellos apoyaran una u otra postura en medio del conflicto.

Lo que podríamos denominar "factores de politización de los militares" son múltiples, que en ocasiones corren por caminos paralelos y en otras se entremezclan. Desde enero hasta diciembre de 1890 las manifestaciones de partidismo político al interior de los líderes del Ejército fueron crecientes y, sin lugar a dudas, se percibió ya en esa época como un factor que distorsionaba la vida política del país y ponía a Chile en el peligroso ámbito del "militarismo" —al menos embrionario- que había hecho historia en el continente americano, plagado de caudillos y revoluciones de los que Chile parecía estar inmune ${ }^{21}$. Entre los factores de politización de los uniformados enunciaremos los siguientes:

En primer lugar, se puede apreciar la presencia de miembros del Ejército en altas funciones de gobierno, específicamente en cargos de ministros de Estado. El punto de inflexión lo representó el nombramiento del general Velásquez como Ministro de Guerra en enero de 1890, con lo que se produjo de hecho la politización del Ejército: era necesario contar con un hombre de sable en el gobierno en medio de la crisis, como resumió un opositor $^{22}$. En segundo término, los militares participaron en meetings políticos y reuniones partidistas, politizando con ello a la institución que representaban. Una de esas reuniones de militares, en homenaje al nuevo ministro Velásquez "marca, en cierto modo, si bien muy vagamente, el origen de

${ }^{21}$ Dicho "germen de militarismo" fue denunciado por El Comercio, de Valparaíso, 29 de mayo de 1890.

22 Véase Zegers, Julio: "Revolución 1891”, p. 5-III, inédito (en Archivo Fernández Larraín, Volumen LXXX). 
la intromisión política en el Ejército"23. Fue tan grave el asunto que en septiembre el nuevo Ministro de Guerra, Federico Errázuriz, decidió que los uniformados evitaran "su asistencia a banquetes u otras manifestaciones de carácter político aunque esos actos sean en honor de personas que desempeñan puestos públicos importantes o se tributen a Jefes del Ejército" ${ }^{24}$. En tercer lugar, se desarrolla una deliberación pública de los militares en política contingente, manifestando opiniones en favor del gobierno y sus políticas (Velásquez y Barbosa) o bien oponiéndose a sus puntos de vista y llamando incluso a la desobediencia de los uniformados hacia el poder ejecutivo (del Canto y Boonen Rivera) ${ }^{25}$. En cuarto lugar, encontramos homenajes a héroes militares, pero que tuvieron un claro contenido político. El caso más emblemático fue el que recibió el general Manuel Baquedano en noviembre de 1890, como se verá en el presente artículo. Otro elemento que es notorio a medida que avanzaba el conflicto en 1890 está reflejado en los viajes presidenciales, los que contaron progresivamente con mayor participación militar, lo que también puede entenderse en la línea del deseo del Presidente de la República por atraerse el favor de los uniformados, "para fortalecer la situación política presidencial", en palabras de Rafael Sagredo ${ }^{26}$. Otro aspecto se refiere a los ataques a distintos uniformados de parte de la prensa partidista de entonces. De esta manera, La Nación denunciaba a los militares más cercanos a la oposición, mientras La Libertad Electoral y El Ferrocarril, por ejemplo, atacaban a los uniformados balmacedistas, por razones profesionales, pero sobre todo por la filiación política de los soldados.

En 1890 también hubo un tema que emergió con fuerza, como fue el asignar a los militares el carácter de garantes de la Constitución y las leyes, que se veían en peligro en medio de la crisis institucional. El tema formó parte del homenaje que recibió Baquedano en noviembre; finalmente ésa sería la fórmula utilizada por los dirigentes opositores para convocar a la rebelión de enero, "designamos a don Jorge Montt para que coadyuve a la acción del Congreso, a fin de restablecer el imperio de la Constitución", era el párrafo final del Acta de Deposición de Balmaceda, que justificó el levantamiento de la Armada en enero de $1891^{27}$.

${ }^{23}$ Blanchard Chessi, Enrique: "La Revolución Chilena de 1891”, 30 de abril de 1910.

${ }^{24}$ Federico Errázuriz al Comandante General de Armas de Santiago, en Ministerio de Guerra, $N^{\circ} 850$, Santiago, 6 de septiembre de 1890.

${ }^{25}$ Un análisis de conjunto sobre este tema en San Francisco, Alejandro: "La Deliberación Política de los Militares Chilenos...”, por aparecer.

${ }^{26}$ Así lo ha destacado recientemente Rafael Sagredo en Vapor al Norte, Tren al Sur, 2001, pp. 239-241, 246-247 y 354-357.

${ }^{27}$ Congreso Nacional: "Acta de Deposición del Presidente Balmaceda", en Memorandum de la Revolución de 1891, 1892, pp. 25-30. 
Lo anterior nos lleva a un último elemento, de la mayor importancia. Frente a la imposibilidad de arribar a un acuerdo estable en el tiempo entre el Presidente Balmaceda y el Congreso Nacional, en diciembre de 1890 tanto los balmacedistas como los opositores hicieron llamados expresos, a través de la prensa o de otras instancias, a las instituciones armadas para que se manifestaran en favor del Ejecutivo o de la oposición parlamentaria, en caso de que llegara - como se presupuestaba - la hora de resolver el asunto por la vía armada. De esta manera los distintos sectores políticos comenzaron a mirar hacia los cuarteles, abandonando la tradición chilena de apoliticismo de las Fuerzas Armadas y provocando, de alguna manera, la última fase del conflicto pre-armado.

Para entonces, los dos últimos meses de 1890, el clima político había sufrido una profunda transformación, caracterizado principalmente por la polarización política entre el gobierno y la oposición, las agresiones continuas y crecientes a través de la prensa, la militarización del discurso político y el abandono de las posibilidades de solución legal del conflicto de poderes. De esta manera, la guerra civil se acercaba a pasos agigantados y la resolución armada de la crisis se tornaba inevitable, al menos con los datos y actitudes presentes a fines de 1890 .

Se podría decir que la clausura del año, y la pendiente inexorable hacia la guerra civil, comenzó con el homenaje al general Manuel Baquedano, realizado el 29 de noviembre en Santiago.

\section{El general Baquedano, garante de la Constitución}

El general Baquedano era considerado, por unánime sentimiento nacional, la figura más destacada en el servicio público, ajeno a las disputas de partido, símbolo claro del triunfo chileno en los campos de batalla de la Guerra del Pacífico: un héroe. Sus camaradas de armas lo recibieron con júbilo: "el pueblo entero de Santiago se agolpó a las puertas de la estación de los ferrocarriles del Estado para tributarle el homenaje de su cariño a su feliz arribo. Desde ese día su casa se ha visto frecuentada por lo más selecto de nuestra sociedad y del ejército" ${ }^{28}$. La Revista Militar de Chile, en tanto, declaró que "el pueblo, sin distinción de clases ni de colores políticos, unánimemente lo aclama en todas partes" 29 .

Sin embargo, la situación era un poco distinta. A fines de 1890 el general Manuel Baquedano recibió un homenaje organizado por la oposi-

${ }^{28}$ El Círculo Militar, Año III, $\mathrm{N}^{\circ} 34,1^{\circ}$ de diciembre de 1890.

${ }^{29}$ Revista Militar de Chile, Tomo X, $\mathrm{N}^{\circ}$ 51, Santiago, $1^{\circ}$ de diciembre de 1890 , p. 286 
ción de la capital, al cual asistieron numerosas personas, pero donde fueron excluidos expresamente aquellos que continuaban como partidarios del Presidente Balmaceda ${ }^{30}$. Días antes de la celebración un diario resumía, a través de un poema, la tarea que Baquedano debía acometer:
Ilustre jeneral, altivo y grande,
Veo en tu sien la lumbre de la gloria,
El rayo de valor brilla en tu mano;
Te veo erguido i fuerte como el Ande;
Pero te resta aun otra victoria:
Defender a la patria de un tirano ${ }^{31}$.

La referencia a la contingencia política es evidente, y la mención a Balmaceda es dura: "un tirano". La idea de realizar el acto tenía un doble origen, propio de los tiempos que corrían. Por una parte, el general estaba volviendo desde Europa, donde había estado durante una prolongada ausencia de su patria, de manera que sus amigos chilenos querían recibirlo como el héroe nacional que era y homenajearlo como correspondía a sus galones. Por otro lado, la situación política del país llevaba a muchas personas a considerar a Baquedano como al principal garante del orden constitucional, amenazado a juicio de los opositores por las actitudes presidencialistas - incluso dictatoriales - de Balmaceda. La forma elegida para rendir tributo a Baquedano fue un banquete de 500 cubiertos en el Teatro Municipal de la capital, evento que fue anunciado por la prensa en numerosas ocasiones.

El acto contó con la mayor solemnidad y tuvo numerosos oradores, representantes de los diferentes partidos políticos que se oponían a la política presidencial. Entre ellos podemos destacar a Eulogio Altamirano, Enrique Mac Iver y Clemente Fabres ${ }^{32}$. Además hablaron en el evento dos hombres que habían representado la última posibilidad de acuerdo entre el Presidente y el Congreso a mediados de año, Álvaro Covarrubias y Belisario Prats. Desde el ámbito militar, los principales oradores fueron el contraalmirante Luis Uribe y el propio general Baquedano.

En la ocasión hubo llamados expresos a Baquedano para asumir un papel de garante de la Constitución y las leyes, en caso de que el Presidente Balmaceda siguiera por la pendiente que lo conducía fuera de los límites republicanos. Las referencias de los discursos eran claras: "héroe destinado por la Providencia para su salvación (de la República)", "sabrá salvar las

\footnotetext{
${ }^{30}$ Orrego Luco, Luis: Memorias del Tiempo Viejo, 1984, p. 312.

${ }^{31}$ El poema, firmado por Voix du peuple, en El Día, 24 de noviembre de 1890.

${ }^{32} \mathrm{El}$ primero de ellos liberal, el segundo radical y conservador el tercero.
} 
leyes y libertades de la República", "General. Mandad y obedeceremos". Un orador resumió de manera elocuente la posición asignada a Baquedano: "Tributemos al ilustre general nuestros agradecimientos, y saludemos de nuevo en él al representante de las glorias del ejército y armada, y al defensor del nombre e instituciones de la República" 33 .

El discurso del general Baquedano es interesante y forma parte de la deliberación política de los militares que precedió a la guerra civil ${ }^{34}$. Lo redactó Máximo Ramón Lira, secretario y amigo personal del héroe mili$\operatorname{tar}^{35}$. No se trataba de un texto terminante, resueltamente contrario al gobierno o que anunciara la inminencia de una intervención militar. Más bien era ecléctico y elusivo. Pero había algunas líneas que daban a entender su postura cercana a la oposición: el éxito de Chile estaba en la bondad de sus instituciones y en las virtudes de sus hijos; pedía que el país se mantuviera libre de manchas; bebió una copa por el porvenir de Chile al amparo de las mismas leyes que habían hecho grande al país ${ }^{36}$.

A pesar de su importancia, la historiografía no ha prestado suficiente atención al homenaje a Baquedano, quizá porque ha olvidado considerar en toda su magnitud el factor político-militar en torno a la guerra civil de 1891. Rodríguez Bravo omite mencionar el evento, al igual que Julio Bañados, Harold Blakemore, Hernán Ramírez N. y Gonzalo Vial ${ }^{37}$; Carmona, el biógrafo de Baquedano, también se olvida del asunto ${ }^{38}$; Ricardo Salas Edwards lo ubica como parte de las postrimerías del régimen constitucional, aunque sin destacar mayormente el hecho ${ }^{39}$; Encina percibe el acercamiento de la oposición a Baquedano como parte de una estrategia política anti-balmacedista ${ }^{40}$. Sin embargo, ninguno de ellos logra penetrar en el contenido profundo del acto y las consecuencias que él tuvo de cara a la lucha político-militar.

${ }^{33}$ Las frases arriba reproducidas fueron parte de los discursos de los líderes de la oposición en el homenaje a Baquedano. Se encuentran transcritas en El Ferrocarril, 30 de noviembre de 1890 .

${ }^{34}$ Lo hemos mencionado en San Francisco, Alejandro: "La Deliberación Política de los Militares Chilenos...", por aparecer.

${ }^{35}$ Orrego Luco, Luis: Memorias del Tiempo Viejo, 1984, pp. 312-313.

${ }^{36}$ El discurso de Baquedano en El Ferrocarril, 30 de noviembre de 1890.

${ }^{37}$ Bañados E., Julio: Balmaceda..., 1894; Rodríguez Bravo, Joaquín: Balmaceda y el Conflicto entre el Congreso y el Ejecutivo, 1921, 1925, 2 tomos; Ramírez Necochea, Hernán: Balmaceda y la Contrarrevolución de 1891, 1958; Blakemore, Harold: Gobierno Chileno y Salitre Inglés 1886-1896: Balmaceda y North, 1977; Bravo, Fernando, Francisco Bulnes y Gonzalo Vial: Balmaceda y la Guerra Civil, 1991.

${ }^{38}$ Carmona, Jorge: Baquedano, 1946.

39 Salas Edwards, Ricardo: Balmaceda y el Parlamentarismo en Chile, 1914, 1925, Volumen I, pp. 374-376.

40 Encina, Francisco A.: Historia de Chile, Tomo XIX, 1970 (segunda edición), pp. 312-315. 
El homenaje, en realidad, tuvo un significado político claro y también un notable contenido simbólico, por cuanto elevó a Baquedano - $-\mathrm{y}$ por extensión a los militares- como "Jefe Supremo del Ejército chileno, guardián de la Constitución", única garantía en medio de la crisis. Como señaló el embajador alemán en Chile, en un documento notable por su síntesis y claridad, un político opositor chileno le había declarado que "en caso de que Balmaceda se lanzase al camino resbaladizo de la dictadura, tendríamos que ver en Baquedano el libertador y —quiéralo él o nonuestro futuro Presidente" 41 . Los partidos comenzaban a mirar los uniformes para encabezar el gobierno del país, en una situación que se repetiría en 1891 con figuras como el general Velásquez, el general Estanislao del Canto, el capitán Jorge Montt y, ciertamente, el propio Baquedano.

Según era de esperarse, la reacción de la prensa y los partidos fue contradictoria, y cubrió ampliamente el acto en favor de Baquedano. Los diarios de oposición destacaron el homenaje al mérito que había significado el evento, que también involucraba un dique "contra la corriente corruptora de hombres y de instituciones" ${ }^{\text {" }}$; se contraponía la soledad del Presidente Balmaceda con lo masivo y amplio de la convocatoria al homenaje al general ${ }^{43}$; otro medio destacaba las múltiples dificultades puestas por el gobierno para la realización del evento, en lo que había fracasado, considerando el gran éxito del acto ${ }^{44}$; asimismo, se resumía la figura de Baquedano como "encarnación purísima de nuestras victorias, símbolo de nuestro buen nombre en el extranjero y grata esperanza en los días nublados de nuestro porvenir" 45 .

La respuesta del gobierno se expresó a través de los periódicos oficialistas y, como era de esperarse, fue abiertamente contraria a la visión de los organizadores del homenaje a Baquedano. Sobre el carácter de General en Jefe que le habían reconocido al héroe del Pacífico en el acto de fines de noviembre, La Nación estimó necesario precisar que se trataba de un título meramente honorífico y que Baquedano no tenía "EL MANDO DEL EJÉRCITO DE CHILE, que por la Constitución corresponde al Presidente de la República. El general Baquedano no tiene en Chile ni siquiera el mando del último de los soldados del ejército" ${ }^{46}$. Como resumen del evento, el periódico balmacedista declaraba: "al calor de los odios y de las

${ }^{41}$ Véase Gutschmid a Caprivi, N 1 , Santiago, 9 de diciembre de 1890 (1891), pp. 34.

\footnotetext{
${ }^{42}$ La Época, 30 de noviembre de 1890.

${ }^{43}$ El Mercurio, 4 de diciembre de 1890.

${ }^{44}$ El Chileno, 30 de noviembre de 1890.

${ }^{45}$ El Estandarte Católico, $1^{\circ}$ de diciembre de 1890.

${ }^{46}$ La Nación, "El Ejército", $1^{\circ}$ de diciembre de 1890. El destacado en el original.
} 
pasiones políticas, realizada en forma artera e insidiosa y persiguiendo un propósito francamente subversivo y trastocador, ha tenido lugar el sábado la manifestación que la coalición oligárquica ofreció al general don Manuel Baquedano, en el Teatro Municipal de Santiago" ${ }^{47}$. Mientras tanto El Comercio reproducía una carta en que se expresaba que Baquedano se había prestado "a servir de juguete a un bando sin conciencia y sin pudor, que sólo ambiciona el poder y el presupuesto" 48 .

Como fuera, ambos sectores hacían la misma evaluación del evento, aunque difirieran en sus afectos: Baquedano se había convertido en un personaje político de la mayor importancia y quedaba claro, a quien quisiera ver, que la oposición había optado resueltamente por atraer al Ejército para enfrentarse a Balmaceda en caso que el Presidente quisiera gobernar a partir del $1^{\circ}$ de enero de 1891 sin la aprobación de las leyes constitucionales por parte del Congreso Nacional. El gobierno, por su parte, no se quedaba atrás, y reafirmaba la doctrina según la cual el representante máximo del Ejército era precisamente el Presidente de la República al que la oposición atacaba sistemáticamente. Según precisó un contemporáneo de los hechos, antibalmacedista, "el banquete a Baquedano llevaba consigo el implícito llamado al Ejército de velar por el cumplimiento de la Constitución y las leyes" ${ }^{\prime 4}$.

Durante diciembre continuarían presentes tanto los llamados a los militares como las disputas constitucionales entre el gobierno y la oposición parlamentaria. Una de ellas, fundamental por su carácter jurídico, constitucional y militar, era la situación de la ley periódica que regiría en 1891 en relación a las Fuerzas Armadas.

\section{El problema constitucional de las fuerzas de mar y tierra}

Uno de los problemas más graves asociados a la crisis institucional de 1890-91 se refiere al problema de las leyes periódicas, es decir, la ley de presupuestos y la ley que fijaba las fuerzas de mar y tierra del país. Si bien ambos son particularmente importantes, el segundo tema cobra una especial consideración si analizamos el papel de las Fuerzas Armadas en el

${ }^{47}$ La Nación, "El Primer Acto de Seducción", 2 de diciembre de 1890. En el mismo documento La Nación explica: "el país sabe bien, como el Ejército y el General Baquedano, que en Chile no hay ni puede haber otro Generalísimo y otro Almirante que el Presidente de la República, al cual deben respeto y obediencia todos los militares, desde el General Baquedano hasta el último marinero".

${ }^{48}$ El Comercio, $1^{\circ}$ de diciembre de 1890.

${ }^{49}$ Orrego Luco, Luis: Memorias del Tiempo Viejo, 1984, p. 314. 
desenlace del conflicto y en el estallido de la guerra civil entre el gobierno de Balmaceda y la oposición parlamentaria.

El artículo 28 de la Constitución de 1833 establecía lo siguiente: "Solo en virtud de una ley se puede:

$3^{\circ}$ Fijar igualmente en cada año las fuerzas del mar y tierra que han de mantenerse en pie en tiempo de paz o de guerra" 50 .

En diferentes períodos de la historia —así lo recordaría Balmaceda en su Manifiesto a la Nación del $1^{\circ}$ de enero de 1891- los años habían comenzado sin que hubieran estado aprobadas las leyes de presupuestos y las que fijaban las fuerzas militares, por lo cual, desde ese punto de vista, la situación no presentaba una gran novedad. Sin embargo, había una diferencia de fondo, omitida por el Presidente de la República en su explicación: en todos los casos que él invocaba como precedentes el Congreso Nacional había seguido sesionando normalmente, de manera que la falta de leyes podía suplirse con la resolución parlamentaria, cuando las cámaras votaran las leyes periódicas pendientes. Era evidente que en 1890 el conflicto Balmaceda-oposición era imposible de solucionar por vías constitucionales, por cuanto el Congreso permanecía clausurado, Balmaceda no manifestaba intenciones de volver a convocarlo y, por ende, 1891 comenzaría como muchos temían que sucediera: sin las leyes constitucionales aprobadas. El conjunto de hechos fue el que puso a Chile en una situación inédita por su gravedad y por las fuerzas políticas y sociales involucradas en la división política del país.

A pesar de la norma expresa de la Constitución, el gobierno insistió a fines de año en la necesidad de interpretar el texto de la carta fundamental de acuerdo a las circunstancias precisas que enfrentaba Chile a fines de 1890. El fundamento de toda la argumentación gubernativa residía en otro artículo de la Constitución, que encargaba al Presidente de la República, ya que "su autoridad se extiende a todo cuanto tiene por objeto la conservación del orden público en el interior, y la seguridad exterior de la República", cuestión que también tenía vigencia en los tiempos de crisis ${ }^{51}$.

La administración se defendía explicando que las cámaras no habían querido aprobar el proyecto de ley que fijaba las fuerzas de mar y tierra para 1891 y, por el contrario, sólo habían dilatado la discusión sobre el particular, mostrando con ello su carencia de voluntad política. A lo anterior se sumaba el argumento histórico mencionado, porque ya habían sido

${ }^{50}$ Constitución Política de la República de Chile, 1833, Artículo 28 (Art. 37 en el texto original).

${ }^{51}$ Constitución Política de la República de Chile, 1833, Artículo 72 (Art. 81 en el texto original). 
muchos los Presidentes de la República, incluido el propio Balmaceda en 1887, que habían gobernado algún tiempo sin que estuvieran previamente aprobadas las leyes periódicas. Por ello, concluía el Diario Oficial en un interesante editorial, "de la práctica comprobada por actos de diversas administraciones y de distintos Congresos, resulta que la ley dictada en 25 de diciembre de 1889 , rige, prácticamente y de hecho, como ha sucedido en ocasiones diversas, hasta que se promulgue otra nueva ley" 52 . Dichas ideas fueron ratificadas en otro editorial del mismo periódico días después, consolidando con ello una interpretación constitucional que, sin embargo, ponía al gobierno al borde de la inconstitucionalidad ${ }^{53}$.

La misma idea sostuvo la prensa balmacedista para apoyar la doctrina constitucional del gobierno. En un editorial de mediados de diciembre, La Nación concluía diciendo: "En suma, durante las administraciones de Prieto, Bulnes, Montt, Pérez, Errázuriz, Pinto, Santa María y Balmaceda, se ha dejado en diversas ocasiones de dar en tiempo oportuno la ley que fija las fuerzas de mar y tierra, sin que por ello nadie haya sostenido que los tales Jefes de Estado se convirtieran por ello en dictadores ni en déspo$\operatorname{tas}^{\prime \prime}{ }^{5}$.

Los partidos y líderes de la oposición, como era de esperarse, pensaban diametralmente distinto. El principal argumento contra el gobierno residía en el hecho que tanto el ejército como la armada requerían para su subsistencia de una ley y que dicho texto no estaba aprobado. Adicionalmente, el Congreso estaba clausurado y nada hacía presentir que antes del 31 de diciembre fueran reabiertas las sesiones para discutir las leyes constitucionales pendientes ${ }^{55}$.

Así lo denunciaba un medio congresista, refiriéndose a la actitud del Ejecutivo y a los argumentos esgrimidos por su prensa. "Y con artificios de tinterillo se dirige ahora al ejército y la armada desde las columnas editoriales del Diario Oficial de la República para persuadirlos de que a él, el Ejecutivo, solo deben obediencia, para convencerlos de que, aun cuando espire la ley que fija su fuerza, siempre continuarán existiendo legalmente siquiera por seis meses más"

Sin embargo, fue en la Comisión Conservadora -integrada por senadores y diputados, y que funcionaba durante el receso parlamentario-

${ }^{52}$ Diario Oficial, "El Ejército y la Armada", 9 de diciembre de 1890.

${ }^{53}$ Diario Oficial, "El Ejército y la Armada", 12 de diciembre de 1890.

${ }^{54}$ La Nación, "Sofismas e Ignorancia", 18 de diciembre de 1890.

${ }^{55}$ Balmaceda rechazó cualquier posibilidad de convocar nuevamente a las sesiones del Congreso, porque podía producirse una acusación constitucional en contra del Ministerio Vicuña.

${ }^{56}$ La Época, "La Dictadura, el Ejército y la Armada", 10 de diciembre de 1890. 
donde la discusión se tornó más agresiva contra las autoridades de gobierno. Ahí los parlamentarios buscaron contradecir el punto de vista presidencial respecto de las leyes constitucionales, profundizando en la idea de que Chile estaría fuera de la Constitución, de las leyes y de las tradiciones republicanas, en caso que el Ejecutivo prorrogara por sí mismo dichas normas sin la aprobación del Congreso.

Desde luego, en el seno de la Comisión Conservadora hubo múltiples llamados al Presidente Balmaceda para que convocara a sesiones del Congreso Nacional, para que fuera éste el que discutiera y aprobara las leyes que fijaban las fuerzas de mar y tierra. Ante la negativa del gobierno y frente a los editoriales del Diario Oficial, de discutible valor doctrinal para los opositores, la Comisión dedicó una sesión completa a debatir el problema de las leyes constitucionales y el punto de vista del Ejecutivo. Pedro Montt inició el debate denunciando "como esas ideas y ese pensamiento tienden a subvertir el orden establecido y a trastornar las verdaderas doctrinas legales y constitucionales". A juicio de Montt, era una prerrogativa exclusiva del Congreso aprobar o posponer las leyes periódicas, por lo que la posición de Balmaceda atentaba contra el régimen parlamentario de gobierno vigente en Chile. Luego el diputado del Partido Nacional agregaba lo siguiente: "se me resiste el alma a aceptar que en pocos días más va a precipitarse el Gobierno voluntaria y deliberadamente en la dictadura y en el despotismo". Por último, Montt proponía un proyecto de acuerdo destinado a precisar la posición institucional sobre el particular, que establecía: "La Comisión Conservadora acuerda manifestar al Presidente de la República que el mantenimiento de las fuerzas de mar y tierra después del 31 de Diciembre, sin que se dicte por el Poder Legislativo la ley que lo autorice, importa una violación abierta del artículo 28 de la Constitución" 57 .

Luego terciaron en la discusión otros parlamentarios de diferentes partidos: Ladislao Errázuriz, Carlos Walker Martínez, José Antonio Gandarillas y Eulogio Altamirano. Todos ellos, sin excepción - los balmacedistas no asistían a la Comisión desde octubre, por considerar que ella funcionaba ilegalmente y no daba garantías a todos los sectores- respaldaron la postura defendida por Pedro Montt y condenaron duramente el artículo del gobierno en el Diario Oficial; además criticaron al Presidente Balmaceda y sus concepciones sobre el sistema de gobierno imperante; denunciaron los deseos gubernativos de establecer una dictadura y vulnerar

${ }^{57}$ Congreso Nacional: Comisión Conservadora, sesión de 10 de diciembre de 1890 , pp. 228-233. 
las instituciones republicanas que enorgullecían al país ${ }^{58}$. Entre los aspectos de mayor interés, sin duda, se encuentra el hecho que los miembros de la Comisión Conservadora, particularmente en relación a las Fuerzas Armadas, enfatizaron dos elementos: por una parte, que no podía haber fuerza pública sin una ley que autorizara su existencia; por otro lado, que los militares no podían actuar contra la Constitución y las leyes, obedeciendo al "capricho de un solo hombre". Como resumió el líder conservador Carlos Walker M., "la dignidad nacional se siente herida en lo más hondo con la tristísima idea de llegar a ver a su Ejército y a su Escuadra convertida en esclavos de un César de comedia... que quiera el cielo no se convierta en tragedia" $"$.

Desgraciadamente, todo parecía indicar que el drama nacional efectivamente se aproximaba. Como prueba suficiente de ello está el hecho de que tanto el gobierno como la oposición comenzaron a apelar a las Fuerzas Armadas para obtener su respaldo en medio de la crisis, dejando de lado así las fórmulas más consensuales o institucionales, para pasar directamente a las vías de hecho o, al menos, para estar preparados en caso de que la lucha por el poder derivara en un enfrentamiento militar.

\section{El gobierno de Balmaceda y la apelación a la subordinación militar}

En medio del conflicto, el Presidente Balmaceda y sus partidarios optaron por reforzar la doctrina tradicional del Ejército en relación al poder político. Como establecía la Constitución de 1833, "La fuerza pública es esencialmente obediente. Ningún cuerpo armado puede deliberar" ${ }^{\circ 0}$. Por ello, el gobierno decidió insistir en la necesidad de la subordinación militar al Presidente de la República, jerárquicamente y sin hacer cuestión del conflicto político. Esto basándose en que el Jefe Supremo de la Nación era también el Generalísimo de las Fuerzas Armadas.

La Nación, el $1^{\circ}$ de diciembre, publicaba un elocuente editorial, titulado "El Ejército". En dicho texto resumía así la posición que debía tener la institución armada: "El Ejército está en su puesto y sabrá conser-

${ }^{58}$ Los defensores del gobierno en la Comisión Conservadora habían sido Baldomero Frías Collao y Julio Bañados Espinosa, que sólo asistieron a las primeras reuniones de la institución.

${ }^{59}$ Congreso Nacional: Comisión Conservadora, sesión de 10 de diciembre de 1890, p. 235 .

${ }^{60}$ Constitución Política de la República de Chile, 1833, Art. 148 (Art. 157 en el texto original). 
varlo", rechazando con ello la sola posibilidad que la oposición parlamentaria lograra convencer a los militares de volverse contra la administración, encabezando una rebelión. Por el contrario, pensaba el periódico balmacedista, al Ejército "nada le hará cambiar su tranquilidad imperturbable, porque vive alimentado con el respeto profundo que debe al Poder Ejecutivo de la Nación; porque las luchas de los partidos no tocan a la Ordenanza General, que es su código, la única ley por la cual se rige, dentro de la subordinación militar y la consideración que dispensa a sus superiores jerárquicos en el servicio" ${ }^{\circ 1}$.

A medida que el mes avanzaba, la prensa seguía insistiendo en los mismos argumentos y el propio Balmaceda continuaba reforzando la lealtad de los máximos jefes militares. Paralelamente, rechazaba las tentativas revolucionarias dirigidas por la oposición y los intentos que hacían por seducir a las instituciones armadas para rebelarse contra el Poder Ejecutivo. Particularmente, rechazaban las proclamas cotidianas que la prensa opositora dirigía "para corromper a los gloriosos soldados del Ejército", cuando los invitaba a resistir al Presidente de la República ${ }^{62}$.

Pocos días antes de terminar el año, El Comercio resumió la posición del gobierno en un corto pero claro mensaje titulado "A nuestro glorioso Ejército". En dicho texto el periódico resumía las ideas centrales del pensamiento balmacedista sobre las Fuerzas Armadas en los tiempos de crisis que se vivían: que el Ejército siempre había sido fiel, respetuoso y obediente de la Constitución y las leyes; que el Ejército no tenía otro superior constitucional que el Jefe Supremo de la Nación, es decir, el Presidente de la República; recordaba que la fuerza pública era esencialmente obediente y que ningún cuerpo armado podía deliberar; que ni el pueblo ni el Congreso podían exigirles a las Fuerzas Armadas que dejaran de cumplir sus deberes constitucionales; que cualquier militar que faltara a la obediencia debida al Presidente de la República se constituía en traidor a la patria. Por último, el diario resumía con dureza lo siguiente: "La coalición opositora no podrá jamás conseguir que haya repugnantes y miserables Judas o traidores a la patria, entre esa falange brillante de hombres de honor y patriotismo, que componen los jefes, militares y soldados del ejército de Chile"63.

${ }^{61}$ La Nación, "El Ejército", 1 de diciembre de 1891.

${ }^{62}$ La Nación, "Fuera de la ley", 29 de diciembre de 1891.

${ }^{63}$ El Comercio, "A Nuestro Glorioso Ejército", 30 de diciembre de 1890. La proclama se reprodujo textualmente el 31 de diciembre, cuando quedaba sólo un día para que llegara la fecha decisiva esperada por todos los sectores. 
Fue esa convicción la que tenía el Presidente Balmaceda a fines de 1890, que le llevaba a esperar y estar seguro del apoyo que le brindarían las instituciones armadas en caso de que algunos chilenos intentaran sublevarse contra su gobierno por las razones que fueran. Obviamente no se trataba simplemente de reproducir artículos de prensa reforzando deberes militares, ni tampoco de concentrar todos los esfuerzos en explicar doctrinas jurídicas a los uniformados. Junto a lo anterior, el gobierno procuró ir asegurando el respaldo del Ejército, particularmente, para evitar una sorpresa desagradable al comenzar 1891. A través de sus figuras más importantes en la institución -Barbosa, Gana, Alzérreca, entre otros- Balmaceda pensó que contaría con el respaldo irrestricto de los héroes de 1879, que habían dado pruebas de su lealtad al gobierno en muchas ocasiones. Los mismos cargos ostentados por esas figuras militares son una prueba suficiente de la confianza del gobierno en algunos de los jefes uniformados: el general Barbosa era Comandante de Armas de Santiago, el general Gana había sido designado como Ministro de Guerra en el Ministerio Vicuña, Alzérreca en tanto era distinguido como Intendente de Santiago. De ellos, sólo el primero desempeñaba un puesto específicamente militar, mientras los otros dos asumían tareas reservadas habitualmente a los civiles: la politización militar de 1890 había marcado un cambio en las tradiciones chilenas y el año terminaba como había comenzado, con generales co-gobernando a través de los gabinetes, por expreso llamado del Presidente de la República ${ }^{64}$.

Era evidente, a fines de año, que la situación podía derivar en una solución de fuerza, por más que las partes en conflicto declararan no querer llegar a una solución extrema. De ahí que La Nación, el principal defensor de la política presidencial a fines de 1890 , sostuviera con dureza y claridad poco antes de la Navidad de ese año: "Opondremos el hierro al hierro y, antes que humillarnos a los imbéciles y los malvados, habremos de caer ejercitando inexorables represalias" ${ }^{\prime 65}$. No era, precisamente, una frase que propusiera un acuerdo pacífico. Los gobiernistas estaban convencidos de las posibilidades de éxito de su postura y basaban su confianza en la lealtad de los militares.

Sin embargo, los opositores trabajaban con igual o mayor fuerza por obtener el apoyo institucional de las Fuerzas Armadas.

${ }^{64}$ Dos textos de testigos directos narran los esfuerzos del gobierno por mantener la lealtad de los militares a fines de 1890 y comienzos de 1891. Ellos son Velasco, Fanor: La Revolución de 1891: Memorias, 1914, y Rodríguez Mendoza, Emilio: Como si Fuera Ayer!..., 1919.

${ }^{65}$ La Nación, "Comparemos", 22 de diciembre de 1890. 


\section{La oposición y el llamado al levantamiento militar contra la dictadura}

Los opositores al Presidente Balmaceda no desconocían la doctrina de las Fuerzas Armadas, sino que reconocían en ella una de las principales razones de la consolidación de la República, que permitieron a Chile mantenerse ajeno al caudillismo y a las rebeliones que azotaban a los demás países del continente. En este sentido, el conjunto de los partidos y los líderes del país estaban orgullosos de la tradición civilista de Chile y de la subordinación de los militares al poder político.

Sin embargo, a fines de 1890 el problema era distinto y el asunto principal dejó de ser la "obediencia sin deliberación", en la que todos estaban de acuerdo. El problema era todavía más complejo, y se refería fundamentalmente a la eventual inconstitucionalidad en que caería el Presidente Balmaceda al comenzar el año siguiente, por carecer de leyes de presupuesto y de aquellas que fijaban las fuerzas de mar y tierra. Frente a esa situación, ¿debían obedecer las Fuerzas Armadas a un gobierno "inconstitucional"? ¿Quedaban en libertad para optar por una u otra parte en conflicto? ¿O debían, derechamente, pronunciarse contra el gobierno de hecho que establecería Balmaceda?

Algunos destacados uniformados ya habían expresado su posición durante 1890 , y ciertamente se podía apreciar una diferencia considerable de opiniones entre los soldados "balmacedistas" y los "opositores". Orozimbo Barbosa, por ejemplo, procuraba enfatizar los mandatos claros de la Constitución y la Ordenanza del Ejército, que obligaban a una subordinación y obediencia sin deliberación a los miembros de las Fuerzas Armadas ${ }^{66}$. Estanislao del Canto, por su parte, había sostenido que la Constitución no se había puesto en el caso de un conflicto entre los poderes del Estado, de manera que en tal situación los militares quedaban en una situación poco común y deberían saber cumplir con su deber, sin especificar la necesidad de seguir al Presidente de la República, sino más bien dejando una puerta abierta para la deliberación de los uniformados en uno u otro sentido ${ }^{67}$.

${ }^{66}$ En agosto Barbosa había pronunciado un discurso en el homenaje al Ministerio Sanfuentes, en el cual declaró lo siguiente: "sabemos bien, como lo sabe el último ciudadano alistado en nuestro ejército, que la constitución nos prohíbe deliberar y que la Ordenanza nos enseñan a acatar y a rendir ciega obediencia a las autoridades legalmente constituidas; a cumplir y hacer cumplir sus órdenes cuando no van reñidas con el honor y la dignidad". El discurso completo se encuentra en La Nación, 16 de agosto de 1890.

${ }^{67}$ En su discurso del 26 de mayo de 1890, con deliberada ambigüedad, del Canto señaló: "debe obedecer a sus jefes, y respetar sobre todo los poderes constituidos: el Legislativo, el Ejecutivo y el Judicial. La Constitución, señores, no ha podido ponerse en el caso de un 
A fines de año la oposición ocupó dos vías principales para convocar a la intervención armada y la revolución contra Balmaceda: la prensa y la Comisión Conservadora. El asunto de fondo sobre el cual descansaba el argumento opositor se refería a la naturaleza del poder que gobernaba Chile y su evidente y abierta inconstitucionalidad, es decir, su carácter dictatorial o tiránico. Los líderes antibalmacedistas declaraban que Chile era un país que se estaba saliendo de la Constitución y las leyes por la acción de un gobierno que esperaba la llegada de un nuevo año sin la aprobación previa de las leyes constitucionales.

El 23 de diciembre La Libertad Electoral fue muy clara en plantear su posición en las instancias decisivas que se vivían en Chile. "Cualquier medio es bueno - decía el medio de prensa opositor-. Lo es la Comisión Conservadora, la prensa, el mitin y lo es también el brazo armado, cuando se han agotado todos los medios y han resultado ser todos ineficaces. Cuando la fuerza del derecho ha dicho su última palabra, tócale hacerse oír al derecho de la fuerza" 68 .

En la misma línea, un periódico democrático se refería así en relación a las instituciones militares: "El ejército será valiente, abnegado para sacrificar su sangre generosa en los campos de batalla en pro de la Patria. Sabrá mantener puro y sin mancha el honor de la bandera contra los que intenten mancillarla; pero nunca será el instrumento de las ambiciones de un gobernante que se ha colocado fuera de toda ley; que no gobierna para el pueblo y por el pueblo" 69 . Era el grito de aviso en favor de la desobediencia militar.

Había otro argumento importante esgrimido por la prensa opositora, referido al vínculo inherente que había entre el pueblo y el ejército, que no podían dividirse en las horas de crisis que vivía Chile. "Por eso, también, no se romperán nunca los lazos vigorosos que unen al ejército y al pueblo y será imposible lanzar a aquel contra éste" ${ }^{\prime 70}$. Se hablaba de que el ejército estaba compuesto por ciudadanos que entendían sus deberes y que vivían en un país libre; que por ello amaban el orden, que en ningún caso podía entenderse como la imposición de una persona sobre el resto; que el ejército y el pueblo tenían un mismo y leal afecto por la Constitución y la patria.

Pero sin duda el documento más importante es uno redactado por Jorge Boonen Rivera, profesor de la Academia de Guerra, a fines de año.

divorcio entre estos poderes. El ejército, aunque en una situación difícil, sabrá cumplir con los mandatos de la Constitución, porque es digno y ama a su patria". El texto del breve discurso en La Nación, 28 de mayo de 1890.

${ }^{68}$ La Libertad Electoral, 23 de diciembre de 1890.

${ }^{69}$ Las Provincias, "El principio del fin", 26 de diciembre de 1890.

${ }^{70}$ La Época, "El Ejército y el Pueblo", 18 de diciembre de 1890. 
En su artículo, publicado en La Época, Boonen declara que "existen y se pueden presentar casos en la vida militar en los cuales la desobediencia sería un deber, porque los intereses de individuos aislados están muy por abajo de los de la patria, que un militar de honor nunca debe olvidar"71. Con ello, no sólo aceptaba la desobediencia como una posibilidad, sino que la consagraba como un deber en el caso concreto de Chile a fines de 1890 y, sobre todo, a comienzos de 1891.

A todo lo anterior se sumaba, obviamente, un hecho de carácter práctico que estaba destinado a preparar las fuerzas en caso de que estallara el conflicto armado: la oposición realizó durante noviembre y diciembre gestiones específicas para ganarse el respaldo de las Fuerzas Armadas y algunos de sus miembros más destacados, y de esa manera resistir lo que ellos denominaban como una intención dictatorial del gobierno. Así lo dan a conocer algunos testigos aventajados de los hechos.

Como señaló uno de los principales revolucionarios, "se estudió atentamente el espíritu del ejército y de la armada y se trató de saber qué idea tenía de sus deberes en caso de violarse las instituciones; se reunieron recursos para adquirir y otros elementos de resistencia" ${ }^{, 72}$. El mismo Julio Zegers, ácido contradictor de Balmaceda y de sus políticas, fue el encargado de sondear al general Baquedano ${ }^{73}$. En el puerto las tareas principales las desarrolló Enrique Valdés Vergara, quien conversó con los marinos y procuró que Jorge Montt y otros estuvieran listos en caso de que el Presidente Balmaceda violara la Constitución ${ }^{74}$.

Además, cuestión de la mayor importancia en un país como Chile, los principales líderes antibalmacedistas prepararon un documento clave, que más tarde se conocería como Acta de Deposición del Presidente Balmaceda. La idea de ese texto era declarar públicamente la ilegalidad e inconstitucionalidad de la administración, particularmente en lo que se refería a comenzar el año gobernando sin estar aprobadas las leyes de presupuesto anual y la que fijaba las fuerzas de mar y tierra.

\footnotetext{
${ }^{71}$ Boonen Rivera, Jorge: "La Obediencia Militar", en La Época, 30 de diciembre de 1890.

72 Zegers, Julio: "Crónica Revolución 1891" (inédito), p. 15-VII. El texto se encuentra en el Archivo Fernández Larraín, volumen LXXX. pp. $169-170$.

${ }^{73}$ Véase Zegers, Julio: "La Revolución de 1891", 3 de enero de 1891, anexo 13,

${ }^{74}$ Orrego Luco, Luis: Memorias del Tiempo Viejo, 1984, pp. 318-320. Orrego Luco narra que las principales gestiones fueron desarrolladas por el joven Enrique Valdés Vergara, que tenía contactos personales en la Marina. Ismael Valdés Vergara, en tanto, expresa que su hermano incluso iba más lejos, y esperaba dar un golpe mediante un asalto a La Moneda en diciembre, idea que finalmente fue abortada. Véase Valdés Vergara, Ismael: La Revolución de 1891, 1970, pp. 5-6.
} 
El primer borrador del documento fue encargado a Enrique MacIver, uno de los principales oradores parlamentarios, miembro del Partido Radical y uno de los más ácidos contradictores de Balmaceda desde su sillón parlamentario. Los opositores encontraron, sin embargo, que el documento no tenía la fuerza necesaria ni los argumentos suficientes como para emprender un movimiento militar contra el gobierno. El segundo borrador lo redactó el líder conservador Abdón Cifuentes, en la noche del 27 al 28 de diciembre. La copia quedó en la casa de Manuel José Yrarrázaval, la máxima figura del Partido Conservador, hacia donde pasaron a firmar todos los que quisieran adherir al movimiento ${ }^{75}$.

El texto era más comprensivo de los abusos e ilegalidades en las que había incurrido el gobierno a juicio de los opositores, e incluía además unas frases finales respecto del liderazgo militar de la revolución. "Y vos, general, que habéis conquistado tantas glorias para la patria, coronad vuestra vida restableciendo el imperio de la Constitución y las leyes". Este llamado al general Baquedano era perfectamente coherente con las insinuaciones abiertas o veladas que se le habían hecho en el banquete de homenaje del 29 de noviembre. Sin embargo, el héroe de 1879 prefirió que esa parte quedara en blanco. "Por ahí pueden pillarme. Mi nombre en blanco", fue su reflexión ${ }^{76}$. En esto habría influido su respeto, casi religioso, por la institución Presidente de la República ${ }^{77}$. Además, durante diciembre, Baquedano fue agasajado por Balmaceda y su familia, quienes le hicieron ver al general su inmenso valor y patriotismo, lo halagaron, y el soldado decidió abandonar la aventura opositora. Días después dejó la capital y se fue al campo durante la guerra civil ${ }^{78}$.

Frente a eso, hubo que rehacer los ejemplares del acta, que estuvieron listos el 29 al anochecer. Los parlamentarios comenzaron a llegar a firmar, sin leer el documento, que se mantenía en celoso secreto, para servir de base a la declaración de ilegalidad del gobierno al comenzar 1891. Es necesario comprender que ésta era una de las exigencias mínimas que planteó Jorge Montt antes de embarcarse en la revolución: una declara-

${ }^{75}$ Una narración de primera mano en Cifuentes, Abdón: Memorias, 1936, Vol. 2, pp. 290-309.

${ }^{76}$ En Encina, Francisco A.: Historia de Chile, 1970 (segunda edición) Tomo XX, p. 67.

77 Así se lo narró Máximo Lira a Luis Orrego Luco, en Orrego Luco, Luis: Memorias del Tiempo Viejo, 1984, pp. 313-314.

78 Yrarrázaval, José Miguel: El Presidente Balmaceda, 1940, Tomo 2, p. 376, nota 149. Baquedano, al finalizar la guerra civil, fue convocado por Balmaceda para presidir un gobierno interino, cuyo único objetivo era resguardar el orden público hasta que se constituyera el gobierno definitivo de los vencedores. El breve "período" del general, apenas un par de días, terminó con más pena que gloria. 
ción escrita y firmada por la mayoría del Congreso ${ }^{79}$. Finalmente, el mismo Montt fue el elegido por las fuerzas congresistas para restablecer el imperio de la Constitución, a comienzos de 1891, razón que lo constituiría en una figura política de primer nivel, hasta alcanzar la Presidencia de la República una vez concluida la guerra civil ${ }^{80}$.

\section{Enero de 1891: gobierno y oposición se juegan sus últimas cartas}

La finalización de 1890 estuvo llena de problemas y amenazas en el ambiente, así como también comenzó a notarse el aire revolucionario y extra-constitucional, al cual contribuían, quizá en igual medida, el gobierno y la oposición. Lo resumió muy bien un periódico opositor casi al terminar diciembre: "El $1^{\circ}$ de enero se acerca, la aurora del nuevo año viene teñida con líneas negras y rojas: tiene las oscuridades del abismo y los reflejos de una catástrofe" $"$. La Nación, en cambio, manifestaba a través de distintos editoriales una confianza excesiva en la continuidad institucional del país: "no habrá revolución, porque toda la lucha se reducirá a lo que vemos. O sea a la lengua y a los papeles" $\$ 2$.

Quizá los dos sectores tenían algo de razón y fundamentos para defender su visión respecto a la crisis que se veía venir. La oposición estimaba que Balmaceda encabezaría una política abiertamente inconstitucional al comenzar el año nuevo, mientras el gobierno estaba convencido de tener la razón en el plano constitucional y de contar con la fuerza en el ámbito armado. En todo caso, era evidente que cualquier análisis tenía una connotación doble que habría sido impensable en otras épocas: por una parte, estaba presente el argumento político-constitucional, propio de la mentalidad de los sectores dirigentes y de las discusiones que habían caracterizado los debates parlamentarios y de la prensa en 1890; por otro lado, un nuevo elemento había asomado en la discusión y no desaparecería por mucho tiempo, como era la fuerza armada y la posibilidad que fuera ella la

${ }^{79}$ Encina, Francisco A.: Historia de Chile, 1970 (segunda edición), Tomo XX, pp. 60-61. Es decir, era necesario que previamente el Congreso depusiera a Balmaceda.

${ }^{80}$ Véase "Acta suscrita por la mayoría del Congreso Nacional" o "Acta de Deposición del Presidente Balmaceda" y también "Nota con que fue acompañada el acta precedente", 6 de enero de 1891 y "Aceptación de don Jorge Montt", 6 de enero de 1891, ambas complementarias del "Acta de Deposición". Ambas en Memorandum de la Revolución de 1891 (1892), pp. 31-32.

${ }^{81}$ La Libertad Electoral, 26 de diciembre de 1890.

${ }^{82}$ La Nación, 24, 26, 29 y 31 de diciembre 1890. 
que inclinara la balanza en uno u otro sentido. Es decir, la política se había militarizado y ello marcaba el comienzo de 1891.

El documento que inauguró el año de la guerra civil fue el Manifiesto del Presidente Balmaceda a la Nación, del $1^{\circ}$ de enero de 1891, publicado en el Diario Oficial y en otros periódicos. En dicho texto el gobernante hizo expresa mención del conflicto constitucional y, especialmente, en relación a las Fuerzas Armadas. Balmaceda declaró que la mayoría del Congreso había "podido excitar al Ejército a la desobediencia de sus jefes jerárquicos". Casi al finalizar el Manifiesto, el Presidente precisó un hecho capital, que ilustraba lo que había sido la realidad chilena a fines de 1890 en materia político-militar: "Se ha incitado al Ejército y a la Armada a la desobediencia y a la revuelta. Empeño vano! El Ejército y la Armada tienen glorias imperecederas conquistadas en la guerra y en la paz. Saben que soy su Jefe constitucional, que por el artículo 148 de la Constitución son fuerzas esencialmente obedientes, que no pueden deliberar, y que han sido y continuarán siendo, para honra de Chile y reposo de nuestra sociedad, la piedra fundamental sobre la cual descansa la paz pública".

Otro aspecto que destacó el Presidente fue que el Congreso había "dejado perecer en los archivos del Congreso los proyectos de ley que presenté para mejorar los sueldos del Ejército y Armada". Al no haber ley de presupuestos, no se podrían pagar los sueldos de los funcionarios públicos. A lo anterior el gobierno contestaba claramente: "no entregaremos el Ejército y la Armada a la miseria" ${ }^{3}$.

La oposición no se mantuvo al margen de la discusión, como es posible imaginar. Por una parte seguía incitando a las Fuerzas Armadas a la desobediencia y la deliberación contra el Poder Ejecutivo, pero de igual forma continuaba con algunos de sus contactos en las instituciones armadas a objeto de asegurar figuras militares para el inminente levantamiento. La prensa también abrió fuego contra la doctrina gobiernista.

Sin duda uno de los documentos principales de la oposición fue el famoso Memorandum Político - el tercero y último de la serie que había comenzado en 1889- de Julio Zegers, publicado en El Ferrocarril el 3 de enero de 1891. Lo interesante es que dicho texto resume muy bien los planteamientos de los congresistas en su conjunto y no exclusivamente de un líder aislado, por muy importante que éste fuera. Zegers respondía irónicamente al manifiesto presidencial: "Si el señor Balmaceda cuenta con la opinión pública, ¿por qué se encierra en la Moneda rodeado de bayonetas, desvelado por el ruido del tambor, por el iquién vive! de los centinelas,

${ }^{83}$ Balmaceda, José Manuel: "Manifiesto a la Nación”, en Diario Oficial, $1^{\circ}$ de enero de 1891. 
por el estrépito de las patrullas de infantería y caballería, en una palabra, por el rumor bélico que todo esto produce? Si tiene la conciencia tranquila ¿por qué impone al ejército los desvelos, las fatigas y el cúmulo de penalidades de la vida de campaña?"84. El diputado opositor tenía razón, por cuanto el gobierno desarrollaba una fuerte presión sobre las instituciones armadas para contar con su respaldo.

Un testigo privilegiado de los acontecimientos de comienzos de enero en La Moneda nos ha dejado sus recuerdos sobre los dramáticos días que vivía Balmaceda y sus seguidores más cercanos. Junto al Presidente pasaban personajes como los generales Gana, Ministro de Guerra, y Barbosa, Comandante de Armas de Santiago, además del General Velásquez, dos veces ministro en 1890. En la casa de gobierno se preguntaban sobre la actitud que tomaría la oposición frente al Manifiesto del Presidente. La respuesta era unánime: "Seguir estrellándose en la lealtad del Ejército" 85. En realidad, ese era el secreto de Balmaceda, quien tenía una confianza ciega en sus generales y con ello se permitía dudar de las posibilidades de éxito de una eventual revolución.

La oposición, sin embargo, trabajaba en el mismo sentido, procurando ganarse el respaldo uniformado para enfrentar a la dictadura que comenzaba a regir en Chile a comienzos de 1891. Había una cierta certeza en cuanto al respaldo de la Marina, si bien los miembros de esta institución habían sido claros al señalar que sólo actuarían en la medida que el Presidente de la República se pusiera fuera de la Constitución, cuestión que ocurrió el $1^{\circ}$ de enero. Con ello, el capitán Jorge Montt y sus compañeros de armas se sintieron en libertad para encabezar el movimiento revolucionario.

Los líderes congresistas estimaban contar también con el respaldo del Ejército, o más bien confiaban que tendrían su definición en caso de que la Marina se levantara, por cuanto la seguirían en defensa de las instituciones. El asunto no era tan claro, como demuestra un diálogo sostenido entre el entonces presidente del Senado, Vicente Reyes, y Eulogio Altamirano, uno de los principales oradores de la oposición. Reyes le preguntó a su visitante sobre los elementos con que contaba el Congreso: "El Ejército — contestó el señor Altamirano- pide dinero; pero la Marina anda bien". La respuesta de Vicente Reyes fue elocuente y profética: "El hecho de que el Ejército piense de un modo y la Marina de otro significa la guerra civil, de la cual se alejan mis principios" ${ }^{26}$. Días después la historia le daría la razón al líder del Senado.

\footnotetext{
${ }^{84}$ Zegers, Julio: Memorandum Político, 3 de enero de 1891, 1891, p. 32.

${ }^{85}$ Rodríguez Mendoza, Emilio: Como si fuera ayer!..., 1919, p. 138.

${ }^{86}$ Rodríguez Mendoza, Emilio: Como si fuera ayer!..., 1919, p. 132.
} 
Un representante diplomático resumió muy bien la dramática situación en la que se encontraba el país a comienzos de enero de 1891: "Es casi seguro que la paz armada dará pronto lugar a la guerra civil. Los líderes de la oposición han mantenido recientemente un silencio ominoso respecto de sus planes, y es bien sabido que ambos partidos están tratando intensamente por todos los medios a su alcance para asegurar los servicios del Ejército y la Armada. Los grandes peligros hacia el futuro parecerían ser que se produzca una división entre el Ejército y la Armada, o que algún soldado ambicioso asumiera el gobierno del país. En estas contingencias Chile podría experimentar los horrores de la guerra civil o los problemas de una dictadura militar: desgracias de las cuales ha gozado inmunidad en los pasados treinta años"87. Mr. Kennedy tenía razón y el 7 de enero de 1891 se produjo el levantamiento de la Armada contra el gobierno de Balmaceda. La actitud de la mayoría del Ejército — si bien no de todos los miembros de esa institución - abriría el camino a la guerra civil que enlutaría al país hasta agosto del mismo año, cuando las tropas congresistas vencieran definitivamente al ejército balmacedista, poniendo fin al gobierno. Con ello terminaba más de un mes de presiones personales y a través de la prensa contra los miembros de las Fuerzas Armadas. Pero dicho final abría paso a la guerra civil.

Es importante resolver por qué la revolución comenzó por la Marina. No cabe duda que casi todos los movimientos para involucrar a los militares en la política durante 1890, tanto del gobierno como de la oposición, se habían referido al Ejército. Ahí estaban los ministros militares, también los discursos de los uniformados, el posible golpe de Estado a mediados de año, el homenaje a Baquedano y los llamados de último minuto durante diciembre. La Marina, en cambio, más bien brillaba por su ausencia. Es que gobierno y oposición estaban convencidos que sólo con el apoyo del Ejército un movimiento armado podía tener posibilidades de éxito. De ahí que Balmaceda se dedicara fundamentalmente a reforzar la lealtad de sus generales, dejando de lado su relación con la Armada ${ }^{88}$.

Un hecho simbólico grafica lo anterior. A mediados de diciembre de 1890 Balmaceda emprendió un viaje al sur a inaugurar un dique en Talcahuano. El Presidente viajó en barco, contra lo acostumbrado por él, pues sabemos que el gobernante habitualmente se desplazaba al norte en barco y al sur en $\operatorname{tren}^{89}$. Esta vez fue diferente porque la situación política también

${ }^{87}$ Mr. Kennedy a Salisbury, FO 16/264, № 3, Santiago, 6 de enero de 1891.

${ }^{88}$ Todo este problema aparece muy bien narrado en Ibarrola, Bernardo: "El Ejército de Balmaceda: Modernización y Crisis", capítulo V, "Salto al abismo: Los militares, la política y la guerra", 2003.

${ }^{89}$ Sagredo, Rafael: Vapor al Norte, Tren al Sur, 2001, pp. 188ss. 
lo era. En el viaje al sur ocurrieron dos hechos dignos de ser recordados. En primer lugar, el almirante Juan Williams Rebolledo, Comandante en Jefe de la Armada, recibió días antes de ese viaje una proclama que lo instaba a modificar el curso del viaje y trasladar al Presidente Balmaceda a la Isla de Juan Fernández, lo que terminaría con el gobierno despótico y permitiría formar una nueva administración respetuosa de la Constitución y las leyes. Finalmente eso no ocurrió, por cuanto Williams no se prestó para esa iniciativa ${ }^{90}$. El segundo hecho se produjo en el viaje mismo, a bordo del Cochrane, donde Balmaceda fue tratado con extrema frialdad por los marinos. Cuando estaba sentado cerca de la torre de mando en la nave, un guardia se acercó a él y le dijo sin más: "Está prohibido estar ahî", en lo que puede ser considerado una falta de respeto o al menos una descortesía contra el Primer Mandatario ${ }^{91}$. Balmaceda tomaría la decisión, improvisada por las circunstancias, de regresar a Santiago en $\operatorname{tren}^{92}$.

En cualquier caso, Balmaceda ya se había equivocado con la Marina. La oposición logró comprometer en diciembre a Jorge Montt, quien dijo que estaba dispuesto a levantarse contra el gobierno si éste se ponía fuera de la Constitución. En estas gestiones fue clave la figura de Enrique Valdés Vergara, redactor de El Heraldo, de Valparaíso, quien tenía buenos contactos en la Marina desde la Guerra del Pacífico ${ }^{93}$. Más allá de las declaraciones grandilocuentes de algunos funcionarios - yo "respondo por la Marina", dijo el Subsecretario de Guerra Salas Lavaqui- la verdad es que el gobierno ya tenía las cartas perdidas a fines de diciembre y comienzos de enero, por más que siguiera conservando una confianza en el con-

${ }^{90}$ La narración de este episodio la hace el propio hijo del Almirante, que escribió años después sus recuerdos de esa época y que se reconocía admirador de Balmaceda. Véase Williams, Héctor: Balmaceda, 1949, pp. 109-111. Balmaceda se lo contó tiempo después a otras personas. Véase, por ejemplo, Velasco, Fanor: La Revolución de 1891, 1914 p. 327.

${ }^{91}$ Véase Rodríguez M., Emilio: Cómo si Fuera Ayer!..., 1919, p. 144. Rodríguez explica que Balmaceda contó este incidente a Williams, el cual aprovechó la ocasión para leerle la epístola mencionada, en que le insinuaban poner preso al Presidente.

${ }^{92}$ Al respecto, Sagredo, Rafael: Vapor al Norte, Tren al Sur, 2001, pp. 367-378. Un diario opositor a Balmaceda mencionó por esos días que "S. E. (Su Excelencia) resolvió hacer el viaje por tierra a causa de que manifiesta gran desconfianza por la Marina", La Época, 17 de diciembre de 1890. Balmaceda mismo dijo que regresaba por tierra para evitarse "cualquier desagrado", en Williams, Héctor: Balmaceda, 1949, p. 113.

93 Sobre las gestiones Enrique Valdés Vergara en la promoción de la revolución, véase el libro de su hermano, Valdés Vergara, Ismael: La Revolución de 1891, 1970, pp. 5-6. Enrique Valdés era un joven impulsivo y había dirigido su prensa con ácidas críticas contra Balmaceda. En diciembre de 1890 pensaba incluso que lo mejor sería un golpe de Estado directo contra La Moneda, donde habría que "apoderarse de la persona de Balmaceda y de obligarlo pacíficamente o por medio de la violencia (por la razón o la fuerza) a someterse o a dimitir el mando", cuestión que llevaría a cabo el propio Enrique. Comenzada la guerra civil fue nombrado Secretario General de la Escuadra y murió en abril de ese año cuando fue hundido el Blanco Encalada. 
junto de las instituciones armadas ${ }^{94}$. ¿Por qué se equivocó tan claramente el Presidente? ¿Confiaba en esas declaraciones de fidelidad de sus colaboradores o estimaba exageradas las prevenciones que algunos le hicieron sobre la deslealtad de los marinos? ${ }^{95}$ Quizá ni lo uno ni lo otro: probablemente la razón de fondo de Balmaceda seguía siendo su confianza, casi ciega, en la institución "Presidente de la República" y en los mandatos constitucionales de obediencia y no deliberación ${ }^{96}$. Y quizá estimaba contar con el respaldo seguro, más claro y visible, del Ejército, con el cual habría material de guerra suficiente para derrotar a cualquier sublevado. La Marina, a ojos de Balmaceda, importaba mucho menos (en la práctica era así: los oficiales de la Armada eran sólo 124, contra los 945 del Ejército, por mencionar un aspecto) ${ }^{97}$.

Para que se produjera el levantamiento, según se ha visto, faltaba solamente una cuestión, que se produjo el 5 de enero: ese día se decretaron los presupuestos para el año 1891, por la sola decisión del Presidente de la República, cuestión que volvía inconstitucional al gobierno. El resultado, doloroso pero esperable a la luz de las circunstancias, fue el levantamiento de la Armada y el fin de la paz que Chile había gozado por décadas. Ni siquiera lograron producir efectos los incentivos económicos que el gobierno les ofreció a los miembros de la Marina para que depusieran su actitud y volvieran al cauce de la obediencia al Poder Ejecutivo ${ }^{98}$.

Jorge Montt, en cuanto líder militar de la revolución, fue expulsado de la Marina "por traidor a la patria", en tanto la Escuadra Nacional sublevada quedó fuera de la ley según un decreto del gobierno ${ }^{99}$. El Ejército, mayoritariamente en un comienzo, permaneció junto al gobierno de José

${ }^{94}$ La frase de Salas Lavaqui en Rodríguez M., Emilio: Cómo si Fuera Ayer!..., 1919, p. 145.

${ }^{95}$ Estas preguntas las plantea Williams, Héctor: Balmaceda, 1949, p. 107.

96 Así lo expresaría con toda confianza y claridad el presidente Balmaceda en su "Manifiesto a la Nación", $1^{\circ}$ de enero de 1891.

${ }^{97}$ Véase Ministerio de Guerra: Memoria de Marina, 1890, p. VI, y Ministerio de Guerra: Memoria de Guerra, 1890, p. 8. Véase también Ibarrola, Bernardo: "El Ejército de Balmaceda: Modernización y Crisis", capítulo V: "Salto al abismo: Los militares, la política y la guerra".

${ }^{98}$ Véanse decretos "Gratificaciones", Santiago, 10 de enero de 1891, y "Aumento de sueldo", Santiago, 12 de enero de 1891, en Boletín de Leyes y Decretos de la Dictadura, pp. 122-123. El primero de ellos ofreció una gratificación equivalente a dos años de sueldo si es que un buque y su tripulación "vuelve a la disciplina y se somete al gobierno"; el segundo decreto, en tanto, fijó un aumento de sueldo de $25 \%$ para los miembros de la Marina que no hubieran tomado parte en la insurrección.

${ }^{99}$ Véanse decretos "Jorge Montt y Javier Molinas", Santiago, 7 de enero de 1891, y "Escuadra Sublevada", Santiago, 9 de enero de 1891, ambos en Boletín de Leyes y Decretos de la Dictadura, pp. 120-121. 
Manuel Balmaceda, aunque durante la guerra civil tuvo muchas defecciones que minaron al ejército gobiernista y, en alguna manera, facilitaron el triunfo opositor. La presión de los civiles en uno y otro sentido, había tenido un efecto político decisivo.

\section{Conclusiones}

Es evidente que la guerra civil de 1891 no fue el resultado de una casualidad o la mera reacción ante un asunto constitucional sin solución a comienzos de año, producto de la ausencia de las leyes de presupuesto y aquella que fijaba las fuerzas de mar y tierra. En efecto, el Congreso había concluido sus sesiones extraordinarias en octubre de 1890, junto con la formación de un nuevo gabinete de carácter exclusivamente presidencial. Con ello, se había eliminado la última posibilidad de solución política al conflicto entre el Presidente Balmaceda y la mayoría parlamentaria.

De ahí en adelante la militarización de la política se hizo pública, abierta y sin retorno; ambos sectores dejaron de lado las ilusiones de un consenso político. Balmaceda reforzó el presidencialismo de su gestión y su falta de voluntad de llegar a acuerdos; la oposición consolidó su intransigencia contraria al gobierno; la prensa continuó su radicalización y extremismo. Sin embargo, lo más importante fue otra cosa: desde el gobierno y la oposición los dirigentes políticos apelaron a la intervención de las Fuerzas Armadas, fuera para defender al Presidente de acuerdo a la obediencia debida constitucionalmente, fuera para levantarse contra ese mismo gobernante según la doctrina del derecho de rebelión.

La invitación a los uniformados fue en privado y en público, en reuniones políticas y a través de la prensa, en ocasiones velada y otras veces abierta. El período definitorio de la crisis se produjo entre fines de noviembre de 1890 y comienzos de enero de 1891, es decir, desde la proclamación-homenaje al general Baquedano de parte de la oposición hasta el levantamiento de la escuadra en la rada de Valparaíso. Durante ese tiempo ambos bandos se esforzaron por explicar a la opinión pública las razones de por qué abandonaban las vías constitucionales y optaban por la resolución armada de la crisis, por qué junto con llamar al apoyo ciudadano insistían en solicitar el refuerzo de las armas.

Incluso si se consideran literalmente los argumentos puntuales de parte de uno y otro, sobresale entre líneas de los editoriales y discursos una idea de fondo que en Chile parecía inconcebible: la incapacidad de llegar a fórmulas de gobierno estable y lograr acuerdos. No cabía en la mentalidad 
parlamentaria la contradicción grave de opiniones entre el gobierno y la oposición, por cuanto era la mayoría del Congreso quien fijaba la composición del gabinete en conjunto con el Presidente y no parecía posible dentro de los cánones institucionales una contradicción profunda e insuperable entre los poderes del Estado. La situación corrió por un camino diametralmente diferente.

En esas circunstancias, los ojos de los políticos se volvieron a los militares, lo que representaba una curiosidad histórica. Los uniformados habían dado glorias a Chile en el ámbito exterior, pero dentro de las fronteras de Chile su misión era esencialmente profesional, obediente y no deliberante, ajena a los conflictos políticos. Pero, por otra parte, también debían obediencia a la Constitución y a las leyes de la República. De manera que la politización de las Fuerzas Armadas en los dos últimos años del gobierno de Balmaceda representó una inversión de la continuidad histórica, un quiebre importante y decisivo. No fueron los militares los que buscaron el poder ni la participación en el gobierno o en la oposición, sino que fueron los políticos quienes los involucraron en la contingencia, sumándolos a la cadena de pasiones desbordadas, odios acumulados y preparación de la guerra civil.

En este sentido, los comentarios de prensa de diciembre de 1890 son ilustrativos y evidentes y, ciertamente, tuvieron un efecto en los actores militares de la crisis. El asunto parece haber estado claro para los líderes civiles del gobierno, como refleja el hecho de que se prohibiera el ingreso de periódicos de oposición al interior de los cuarteles a mediados de diciembre $^{100}$. Tanto Balmaceda como la oposición sabían que se aproximaba rápidamente el año nuevo y con ello una situación de enorme significación: el país comenzaría enero sin leyes de presupuesto ni leyes que fijaran las fuerzas de mar y tierra; el Congreso Nacional permanecía cerrado, por tanto no podía despachar dichas leyes. La situación era un juego de suma cero, pero con el agravante obvio de la inconstitucionalidad en que ingresarían las instituciones del país. ¿Qué debían hacer las Fuerzas Armadas en dicha situación? ¿Tenían que seguir pasivamente al Presidente Balmaceda, sin hacer cuestión de los problemas jurídicos? ¿Debían levantarse contra su gobierno, considerando que éste comenzaba a gobernar fuera de los límites de la Constitución? Precisamente esas posturas fueron las que promovieron el gobierno —obediencia sin deliberación — y la oposición — rebelión contra la dictadura. De manera que al comenzar enero de 1891 las instituciones armadas habían estado sumidas en una vorágine de incitaciones y amena-

${ }^{100}$ La información de esta prohibición en El Día, 19 de diciembre de 1890. 
zas, invitaciones a obedecer o a insubordinarse, presiones para actuar en uno u otro sentido.

El resultado fue el peor previsible, desde el punto de vista del conflicto: las Fuerzas Armadas se dividieron —entre ellas y al interior de cada una de ellas-, iniciándose la guerra civil. Si todos hubieran permanecido junto al gobierno, no habría habido rebelión armada; si el conjunto de las instituciones armadas se hubieran sublevado, Balmaceda habría tenido que dejar el poder por la fuerza. La división del Ejército y la Armada determinó la profundización de la crisis, provocándose una guerra que dejaría al país con dos gobiernos, dos territorios y dos ejércitos luchando entre sí. La convocatoria a la intervención militar a fines de 1890 había rendido sus frutos a comienzos de 1891, pero el resultado era una tragedia que se extendería por varios meses y dejaría miles de muertos en los campos de batalla.

\section{REFERENCIAS BIBLIOGRÁFICAS}

\section{Prensa periódica:}

El Chileno.

El Comercio, Valparaíso.

El Día.

El Estandarte Católico.

El Ferrocarril.

El Mercurio, Valparaíso.

Diario Oficial.

La Época.

La Libertad Electoral.

La Nación.

Las Provincias.

The Chilian Times, Valparaíso.

Otras publicaciones periódicas:

El Círculo Militar.

Revista Militar de Chile.

\section{Documentos oficiales:}

Boletín de Leyes y Decretos de la Dictadura. Santiago: Imprenta Nacional, 1892.

Constitución Política de la República, 1833.

Congreso Nacional: Cámara de Senadores, 1890.

Congreso Nacional: Cámara de Diputados, 1890.

Congreso Nacional: Comisión Conservadora, 1890.

Memorandum de la Revolución de 1891. Santiago: Imprenta Cervantes, 1892.

Ministerio de Guerra: Memoria de la Marina, 1890.

Ministerio de Guerra: Memoria de Guerra, 1890. 


\section{Otra bibliografía consultada:}

Balmaceda, José Manuel: Mensaje Presidencial de 1890. En Congreso Nacional, Cámara de Senadores, sesión de las Dos Cámaras Reunidas el $1^{\circ}$ de junio de 1890.

Balmaceda, José Manuel: “Manifiesto a la Nación”, $1^{\circ}$ de enero de 1891, en Diario Oficial.

Bañados Espinosa, Julio: Balmaceda, su Gobierno y la Revolución de 1891, 2 tomos. París: Garnier Hermanos, 1894.

Blanchard Chessi, Enrique: "La Revolución Chilena de 1891". En revista Zig-Zag, № 230 al 512, Santiago, 1909-1914.

Blancpain, Jean-Pierre: "L'Armée Chilienne et les Instructeurs Allemands en Amérique Latine (1885-1914)". En Revue Historique N 578, Avril-Juin, 1991.

Blakemore, Harold: Gobierno Chileno y Salitre Inglés 1886-1896: Balmaceda y North. Santiago: Edit. Andrés Bello, 1977.

Boonen Rivera, Jorge: “La Obediencia Militar”. En La Época, 30 de diciembre de 1890.

Bravo, Fernando; Francisco Bulnes y Gonzalo Vial: Balmaceda y la Guerra Civil. Santiago: Editorial Fundación, 1991.

Brahm, Enrique: Preparados para la Guerra: Pensamiento Militar Chileno bajo Influencia Alemana 1885-1930. Santiago: Ediciones Universidad Católica de Chile, 2003.

Braudel, Fernand: El Mediterráneo y el Mundo Mediterráneo en la Época de Felipe II. México: Fondo de Cultura Económica, Vol. 1, 2002.

Carmona, Jorge: Baquedano. Santiago, 1946.

Cheyre, Juan Emilio: “2003. Un Desafío Futuro”. En La Tercera, 5 de enero de 2003.

Cifuentes, Abdón: Memorias. Santiago: Ed. Nascimento, Vol. 2, 1936.

Collier, Simon: "Cuatro Hombres de Armas en la Formación y la Consolidación de la República". En Simon Collier y otros, Patriotas y Ciudadanos. Santiago, CED, 2003.

Congreso Nacional: "Acta de Deposición del Presidente Balmaceda". En Memorandum de la Revolución de 1891. Santiago: Imprenta Cervantes, 1892.

Edwards, Alberto: La Fronda Aristocrática. Santiago: Editorial Universitaria, 13a edición, 1992.

Encina, Francisco Antonio: Historia de Chile. Santiago: Editorial Nascimento, $2^{\mathrm{a}}$ edición, Tomo XIX, 1970.

Errázuriz, Federico: Ministerio de Guerra $N^{\circ} 850$, Santiago, 6 de septiembre de 1890. En Archivo General del Ejército, Fondo Histórico, tomo $\mathrm{N}^{\circ} 529$.

Fontaine Talavera, Arturo: "Debate sobre la Posición de las FF. AA. frente al Gobierno Militar". En Estudios Públicos, 91 (2003).

Góngora, Mario: Ensayo Histórico sobre la Noción de Estado en Chile en los Siglos XIX y XX. Santiago: Editorial Universitaria, 8 a edición, 2003.

Gutschmid (embajador de Alemania en Chile). Nota de Gutschmid a Caprivi, $\mathrm{N}^{\circ}$ 1. En Los Acontecimientos de Chile (documentos publicados por la Cancillería alemana). Valparaíso: Imprenta de la Patria, 1891.

Heise, Julio: Historia de Chile. El Período Parlamentario, 1861-1925. Santiago, Editorial Andrés Bello, Tomo I, 1974.

Kennedy, John Gordon: Nota a Salisbury, FO16/264, Santiago, 6 de enero de 1891. (Archivo del Foreign Office, Kew, Londres.)

Ibarrola, Bernardo: "El Ejército de Balmaceda: Modernización y Crisis. Las Fuerzas Chilenas de Mar y Tierra, 1884-1890". Tesis doctoral, Programa de América Latina Contemporánea, Instituto Universitario de Investigación Ortega y Gasset, Madrid, 2003.

Johnson, John: The Military and Society in Latin America. California: Standford University Press, 1964. 
Lieuwen, Edwin: Arms and Politics in Latin America. New York: Praeger Paperbacks, edición revisada, 1961.

Lynch, John: Caudillos in Spanish America 1800-1850. Oxford: Oxford University Press, 1992.

Millar, René: "Significados y Antecedentes del Golpe Militar de 1924". En Historia No 11, 1972-1973.

Nunn, Frederick: Chilean Politics, 1920-1931: The Honorable Mission of the Armed Forces. Albuquerque: University of New Mexico Press, 1970.

Nunn, Frederick: "Emil Körner and the Prussianization of the Chilean Army: Origins, Process and Consequences, 1885-1920". En Hispanic American Historical Review $\mathrm{N}^{\circ}$ 50, 2 (1970).

Núñez P., Jorge: "La Política Militar del Presidente Balmaceda". En Luis Ortega (editor), La Guerra Civil de 1891: Cien años hoy. Santiago: Universidad de Santiago de Chile, 1993.

Orrego Luco, Luis: Memorias del Tiempo Viejo. Santiago: Ediciones Universidad de Chile, 1984.

Quiroga, Patricio y Carlos Maldonado: El Prusianismo en las Fuerzas Armadas Chilenas: Un Estudio Histórico, 1885-1945. Santiago: Ediciones Documentas, 1988.

Ramírez Necochea, Hernán: Balmaceda y la Contrarrevolución de 1891. Santiago: Editorial Universitaria, 1958.

Rodríguez Bravo, Joaquín: Balmaceda y el Conflicto entre el Congreso y el Ejecutivo. Santiago: Imprenta Gutenberg, 1921, e Imprenta Cervantes, 1925.

Rodríguez Mendoza, Emilio: Como si Fuera Ayer!..., Santiago: Casa Editorial Minerva, 1919.

Rojas, Gonzalo: "Debate sobre la Posición de las FF.AA. frente al Gobierno Militar". En Estudios Públicos, 91 (2003).

Sagredo, Rafael: Vapor al Norte, Tren al Sur: El Viaje Presidencial como Práctica Política en Chile, Siglo XIX. Santiago: DIBAM, 2001.

Salas Edwards, Ricardo: Balmaceda y el Parlamentarismo en Chile. Vol. I. Santiago: Imprenta y Litografía Universo, 1914 y 1925.

San Francisco, Alejandro: "Las Intervenciones Militares en Chile: Patrones y Modelos en la Guerra Civil de 1891, los Golpes Militares de 1924-25 y la Intervención Militar de 1973”. Conferencia en la Academia de Guerra del Ejército, 26 de agosto de 2003.

San Francisco, Alejandro: "El Ejército, la Historia y la Responsabilidad Institucional". En La Segunda, 6 de enero de 2003.

San Francisco, Alejandro: "Las Batallas de la Pluma: La Prensa y el Odio Político en Chile en el Preludio de la Guerra Civil de 1891". En Ángel Soto (ed.), Entre Tintas y Plumas: Historias de la Prensa Chilena del Siglo XIX. Santiago: Universidad de los Andes, 2004.

San Francisco, Alejandro: "La Deliberación Política de los Militares Chilenos en el Preludio de la Guerra Civil de 1891". Por aparecer en Historia 38, № 1, 2005.

Sater, William y Holger Herwig: The Grand Illusion. The Prussianization of the Chilean Army. Lincoln y London: University of Nebraska Press, 1999.

Silva, Fernando y otros: Historia de Chile, Tomo 4. Santiago: Editorial Universitaria, $8^{\text {a }}$ edición, 1988.

Valdés Vergara, Ismael: La Revolución de 1891. Santiago: Editorial Francisco de Aguirre, 1970.

Velasco, Fanor: La Revolución de 1891: Memorias. Santiago: Imprenta y Litografía Universo, 1914. 
Vial, Gonzalo: "Alessandri y los Golpes Militares". En Gonzalo Vial, Historia de Chile, Vol. 3. Santiago, Zig Zag, 2001.

Williams, Héctor: Balmaceda. Santiago: 1949.

Yrarrázaval, José Miguel: El Presidente Balmaceda. Tomo 2. Santiago: Editorial Nascimento, 1940.

Zegers, Julio: "Revolución 1891”. Inédito. En Fondo Archivo Fernández Larraín, Vol. LXXX, Archivo Nacional de Chile.

Zegers, Julio: Memorandum Político. Santiago, Imprenta Cervantes, Octubre de 1891. 